\author{
Universidade de São Paulo \\ Faculdade de Economia, Administração e Contabilidade de \\ Ribeirão Preto \\ Departamento de Economia \\ Programa de Pós-graduação em Economia Aplicada
}

\title{
Associação entre violência e habilidades socioemocionais dos alunos de ensino médio
}

Karen Granzotto Oliani

Orientador: Prof. Dr. Luiz Guilherme Scorzafave

Ribeirão Preto 
Prof. Dr. Marco Antonio Zago

Reitor da Universidade de São Paulo

Prof. Dr. Dante Pinheiro Martinelli

Diretor da Faculdade de Economia, Administração e Contabilidade de Ribeirão Preto

Prof. Dr. Renato Leite Marcondes

Chefe do Departamento de Economia

Prof. Dr. Cláudio Lucinda

Coordenador do Programa de Pós-graduação em Economia Aplicada 


\title{
KAREN GRANZOTTO OLIANI
}

Associação entre violência e habilidades socioemocionais dos alunos de ensino médio

\begin{abstract}
Dissertação apresentada ao Programa de Pós-Graduação em Economia - Área: Economia Aplicada da Faculdade de Economia, Administração e Contabilidade de Ribeirão Preto da Universidade de São Paulo para obtenção do título de Mestre em Ciências. Versão Corrigida. A original encontra-se disponível na FEA-RP/USP.
\end{abstract}

Orientador: Prof. Dr. Luiz Guilherme Scorzafave

Ribeirão Preto 
Autorizo a reprodução e divulgação total ou parcial deste trabalho, por qualquer meio convencional ou eletrônico, para fins de estudo e pesquisa, desde que citada a fonte.

Oliani, Karen Granzotto

Associação entre violência e habilidades socioemocionais dos alunos de ensino médio/ Karen Granzotto Oliani; Orientador: Prof. Dr. Luiz Guilherme Scorzafave Ribeirão Preto, 2016- 66 p. : il.

Dissertação (Mestrado) - Universidade de São Paulo, 2016.

1. Educação 2. Habilidades Socioemocionais 3. Exposição à Violência I. Orientador: Prof. Dr. Luiz Guilherme Scorzafave II. Universidade de São Paulo - USP - Ribeirão Preto. III. Faculdade de Economia Administração e Contabilidade. IV. Associação entre Violência e Habilidades Socioemocionais dos Alunos de Ensino Médio 


\section{Agradecimentos}

Essa dissertação simboliza um grande passo na minha vida. O curso de mestrado em economia aplicada foi fundamental para a consolidação da minha formação como economista e, durante esse período, evolui não só na carreira acadêmica, mas também no âmbito pessoal e profissional. Por isso, gostaria de agradecer a todos aqueles que contribuiram com esse trabalho ou que participaram dessas mudanças de alguma forma.

Em especial, agradeço ao meu professor e orientador Luiz Guilherme por ser responsável pelo início de tudo, ao me chamar para fazer iniciação científica com ele, há quase sete anos atrás. Por ter confiado na minha capacidade e no meu trabalho, por todo o conhecimento passado, pelas oportunidades oferecidas, pela disponibilidade, pela paciência, por ter me motivado a ingressar nesse curso de mestrado: meu muito obrigado.

Gostaria de agradecer ao professor Daniel Santos, que me introduziu ao mundo das habilidades socioemocionais, e também à professora Elaine Pazello, que sempre me apoiou ao longo de minha vida acadêmica. Aos dois, obrigada por toda a ajuda, todas as conversas e todas as sugestões. Não posso deixar de agradecer a todos os professores da FEA-RP/USP, tanto do programa de graduação quanto da pós, vocês foram fundamentais nessa caminhada. Agradeço também ao professor Rudi Rocha, da UFRJ, pelas ideias quando eu ainda estava só no projeto e pelas dicas quando eu já estava no final do trabalho.

Um enorme agradecimento a todos os queridos integrantes do LEPES (Laboratório de Estudos e Pesquisas em Economia Social), vocês foram todos muito importantes para o meu sucesso nesse curso. Agradeço em especial ao Gabriel Bechelli e ao Henrique Velasco, que empenharam grandes esforços nessa pesquisa. Obrigada Beatriz Willemsens, Lucas Lima, Elder Generozo e Jaqueline Natal pela ajuda por whatsapp. Obrigada também aos colegas de mestrado, principalmente a Fernanda Mundim, Juliana Oliveira e Victória Martinez, que tornaram os momentos de preocupação mais tranquilos e as horas na salinha de estudo mais divertidas.

Agradeço aos meus amigos e a toda a família pela compreensão nos momentos em que me ausentei por conta das provas ou da dissertação e por todo o suporte dado ao longo desse processo. Agradeço ao meu irmão, Giovani, pelas conversas sobre programação e pela companhia nos finais de semana em que não viajamos para ficar estudando. Mas o maior agradecimento de todos vai para os meus pais, por terem me proporcioado uma educação de excelência e me apoiado durante toda a vida. Espero que um dia todas as crianças brasileiras possam ter essa oportunidade. 


\section{Resumo}

OLIANI, K. G. Associação entre violência e habilidades socioemocionais dos alunos de ensino médio. 2016. Dissertação (Mestrado) - Faculdade de Economia, Administração e Contabilidade de Ribeirão Preto, Universidade de São Paulo, Ribeirão Preto, 2016.

O presente estudo se propõe a examinar a associação entre exposição à violência e as habilidades socioemocionais de alunos do ensino médio da rede pública do estado do Rio de Janeiro, dada a hipótese de que essas últimas funcionariam como mediadoras de parte do efeito da violência sobre desempenho escolar. A base de dados utilizada foi concebida pelo Instituto Ayrton Senna e a OCDE, que elaboraram uma ferramenta para a mensuração das habilidades socioemocionais desses estudantes. A relação foi estudada para alunos do $1^{\circ}$ e $3^{\circ}$ anos do ensino médio. Conclui-se que as habilidades socioemocionais mais associadas à criminalidade são amabilidade, extroversão e abertura a novas experiências, cujas relações demonstraram coeficientes negativos. A categoria de crimes que mais apresentou relação com as características analisadas foi a de crimes violentos contra patrimônio. Amabilidade e abertura a novas experiências se revelaram como mediadoras de uma pequena parcela do efeito da violência sobre as proficiências de matemática e língua portuguesa.

Palavras-chaves: Exposição à violência. Habilidades Não Cognitivas. Ensino Médio. 


\section{Abstract}

OLIANI, K. G. The association between soft skills and community violence for high school students. 2016. Master's Thesis - School of Economics, Business Administration and Accounting, University of São Paulo, Ribeirão Preto, 2016.

This study aims to explore the association between exposure to violence and public school student's soft skills, given the hypothesis that these latter ones would be mediators of the effect of violence over scholar performance. The data base utilized was developed by the Ayrton Senna Institute and the Organization for Economic Cooperation and Development and aimed to elaborate a tool for measuring soft skills of aproximatly 25 thousand students of Rio de Janeiro state public schools. The relation was analyzed for students in the first and last year of high school. The soft skills most associated with the violence indicators used were agreeableness, extraversion and openness to experience, with negative coeficients. The crimes that showed stronger relations with these characteristics were crimes against property. Agreeableness and openness to experience revealed themselves as mediators of the effect of violence over math and portuguese language grades.

Key-words: Exposure to violence. Soft Skills. High School. 


\section{Sumário}

Sumário . . . . . . . . . . . . . . . . . . 7

Lista de ilustrações . . . . . . . . . . . . . . . . . . . 8

Lista de tabelas . . . . . . . . . . . . . . . . . . . 9

$1 \quad$ Introdução . . . . . . . . . . . . . . . . 11

2 Revisão de Literatura . . . . . . . . . . . . . . . . . . . . . . . 13

2.1 Importância das Habilidades Socioemocionais . . . . . . . . . . . . . 13

2.2 Habilidades Socioemocionais na Educação . . . . . . . . . . . . . . 15

2.3 Exposição à Violência e sua Relação com as Habilidades Socioemocionais . 16

3 Metodologia e Dados . . . . . . . . . . . . . . . . 21

$3.1 \quad$ Dados . . . . . . . . . . . . . . . . . . . 21

3.1.1 Base de Dados das Habilidades Socioemocionais . . . . . . . . . . . . . . 21

3.1.2 Base de Dados de Violência do Instituto de Segurança Pública . . . . . . . . . . . . 21

3.1.3 Manipulação e Compatibilização das Base de Dados . . . . . . . . . . . . . . . 23

3.2 Metodologia . . . . . . . . . . . . . . . . 24

$4 \quad$ Análise Descritiva . . . . . . . . . . . . . . . 27

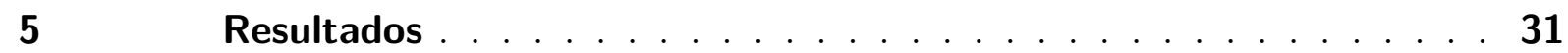

5.1 Estimações por Mínimos Quadrados Ordinários . . . . . . . . . . . . . 32

5.2 Gráficos das Regressões Quantílicas . . . . . . . . . . . . . . . . 47

$5.3 \quad$ Análise de Mediação . . . . . . . . . . . . . . . . 48



Referências ..................... 55

Apêndice ........................ . . 58 


\section{Lista de ilustrações}

Figura 1 - Gráfico dos Coeficientes da Regressão Quantílica de Conscienciosidade e Crimes Violentos Não Letais - $1^{\circ}$ ano do EM . . . . . . . . . . . . . . 47

Figura 2 - Gráfico dos Coeficientes da Regressão Quantílica de Estabilidade Emocional e Crimes Violentos Contra Patrimônio - $3^{\circ}$ ano do EM . . . . . . 48 


\section{Lista de tabelas}

Tabela 1 - Crimes no Estado do Rio de Janeiro 100 mil/hab - Média entre 2012 e

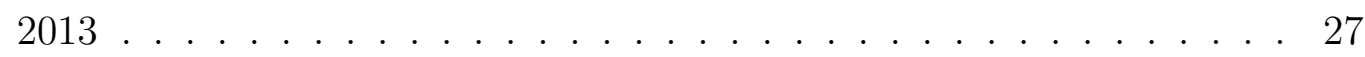

Tabela 2 - Teste de Diferenças de Médias das Variáveis de Habilidades Socioemocionais por Escolaridade da Mãe . . . . . . . . . . . . . . . . 28

Tabela 3 - Teste de Diferença de Médias das Variáveis de Habilidades Socioemocionais por Sexo . . . . . . . . . . . . . . . . . . 29

Tabela 4 - Testes de Diferença de Médias das Variáveis de Habilidades Socioemocionais por Proficiência de Língua Portuguesa . . . . . . . . . . . . . . 29

Tabela 5 - Teste de Médias das Variáveis de Habilidades Socioemocionais por Proficiência de Matemática . . . . . . . . . . . . . . . . . . 30

Tabela 6 - Correlações entre Habilidades Socioemocionais, Indicadores de Violência e Proficiências . . . . . . . . . . . . . . . . . . . . . 31

Tabela 7 - Relação entre Habilidades Socioemocionais e Violência - $1^{\circ}$ ano do EM 32

Tabela 8 - Relação entre Habilidades Socioemocionais e Violência - $3^{\circ}$ ano do EM 34

Tabela 9 - Relação entre Habilidades Socioemocionais e Violência por Escolaridade da Mãe $-1^{\circ}$ ano do EM . . . . . . . . . . . . . . . . . 35

Tabela 10 - Relação entre Habilidades Socioemocionais e Violência por Escolaridade da Mãe $-3^{\circ}$ ano do EM . . . . . . . . . . . . . . . . . 37

Tabela 11 - Relação entre Habilidades Socioemocionais e Violência por Sexo - $1^{\circ}$ ano do EM . . . . . . . . . . . . . . . . . . . 38

Tabela 12 - Relação entre Habilidades Socioemocionais e Violência por Sexo - $3^{\circ}$ ano do EM . . . . . . . . . . . . . . . . . . . . . . . . . 40 40

Tabela 13 - Relação entre Habilidades Socioemocionais e Violência por Proficiência $-1^{\mathrm{o}}$ ano do EM . . . . . . . . . . . . . . . . 42

Tabela 14 - Relação entre Habilidades Socioemocionais e Violência por Proficiência - $3^{\circ}$ ano do EM . . . . . . . . . . . . . . . . . . 45

Tabela 15 - Análise de Mediação da Relação entre Violência e Proficiências de Matemática através das Habilidades Socioemocionais - $1^{\circ}$ ano do EM . . .

Tabela 16 - Análise de Mediação da Relação entre Violência e Proficiências de Língua Portuguesa através das Habilidades Socioemocionais - $1^{\circ}$ ano do $\mathrm{EM} \ldots \ldots \ldots \ldots \ldots \ldots$

Tabela 17 - Análise de Mediação da Relação entre Violência e Proficiências de Matemática através das Habilidades Socioemocionais - $3^{\circ}$ ano do EM . . . 51

Tabela 18 - Análise de Mediação da Relação entre Violência e Proficiências de Língua Portuguesa através das Habilidades Socioemocionais - $3^{\circ}$ ano do $\mathrm{EM}$ 
Tabela 19 - Relação entre Habilidades Socioemocionais e Crimes Letais Intencionais $-1^{\mathrm{o}}$ ano do EM . . . . . . . . . . . . . . . . 58

Tabela 20 - Relação entre Habilidades Socioemocionais e Crimes Não Letais - $1^{\circ}$ ano do EM . . . . . . . . . . . . . . . . . . . . 5 59

Tabela 21 - Relação entre Habilidades Socioemocionais e Crimes Contra Patrimônio $-1^{\circ}$ ano do EM . . . . . . . . . . . . . . . . . 60 60

Tabela 22 - Relação entre Habilidades Socioemocionais e Violência por Quantil $1^{\circ}$ ano do EM . . . . . . . . . . . . . . . . . . . 61

Tabela 23 - Relação entre Habilidades Socioemocionais e Violência por Quantil $3^{\mathrm{o}}$ ano do EM . . . . . . . . . . . . . . . . . . . . . . . . . 62 


\section{Introdução}

A garantia de um ensino de qualidade à população é fator crucial para o desenvolvimento dos países (ROMER, 2006). No que diz respeito ao Brasil, houve grande progresso na inclusão das crianças e adolescentes na educação básica nos últimos 20 anos. Entretanto, apesar da melhora no acesso e na permanência dos alunos na escola, as avaliações externas, como SAEB (Sistema Nacional de Avaliação da Educação Básica) e a Prova Brasil, mostraram uma evolução tímida no desempenho dos estudantes, principalmente para o ensino médio. Entre 2001 e 2011, as notas médias de matemática e língua portuguesa avançaram 0,2 e 7,6 pontos para $3^{\circ}$ ano do ensino médio, respectivamente, o que representa uma melhora pequena na escala SAEB. Dessa forma, abrasado por tais resultados, tem tomado força o debate sobre como oferecer uma educação de qualidade na rede pública brasileira de ensino.

Desde a publicação do relatório Coleman et al. (1966), foi demonstrado que os fatores extra-escolares, como o background familiar do aluno, explicam mais das desigualdades observadas no desempenho do que os próprios fatores intra-escolares (experiência dos professores, salários e infraestrutura da escola). Esse resultado tem sido corroborado mais recentemente tanto para o Brasil (ALBERNAZ; FERREIRA; FRANCO, 2002) quanto para os Estados Unidos (LEE; BURKAM, 2002).

Nos últimos anos, tem sido investigado como as habilidades socioemocionais estão associadas ao sucesso escolar dos alunos. Tais habilidades, também denominadas não cognitivas ou soft skills, compreendem fatores como sociabilidade, curiosidade, disciplina, autocontrole, entre outras. Gonçalves, Raposo e Gomes (2014), por exemplo, descobriram que alunos que apresentaram um autoconceito positivo de sua personalidade ou que se sentem valorizados por seus colegas de turma e professores tendem a exibir um melhor desempenho acadêmico. Cia e Barham (2009) encontram relação positiva entre o desempenho acadêmico e as habilidades sociais de crianças no início do ensino fundamental. Santos e Primi (2014) mostram que a conscienciosidade possui grande impacto sobre a nota de alunos do ensino básico. Entretanto, cabe ressaltar que a importância dessas competências transpõe o contexto escolar. Por exemplo, Almlund et al. (2011) demonstraram 
que existe uma forte associação entre os habilidades socioemocionais de um indivíduo e seu desempenho no mercado de trabalho, suas condições de saúde e a probabilidade de envolvimento com atividades criminosas.

Heckman (2011) e Borghans et al. (2008) defendem que essas características são maleáveis ao longo da vida, principalmente na infância. Assim, é possível que as experiências de vida de uma pessoa, tanto dentro quanto fora do ambiente escolar, possam alterar seus traços de personalidade. Ainda há pouca evidência de que políticas educacionais específicas afetam o desempenho dos alunos por meio de habilidades socioemocionais. Heckman, Pinto e Savelyev (2012), por exemplo, em um estudo sobre o programa Perry Preschool, concluem que o principal canal através do qual o efeito positivo do projeto de educação infantil se deu foi o de mudanças induzidas na personalidade dos indivíduos tratados.

Se programas educacionais específicos podem exercer esse efeito sobre as habilidades socioemocionais, a princípio, outros fatores também têm essa capacidade. Nessa pesquisa, será avaliada especificamente a influência da violência no entorno da escola sobre as habilidades socioemocionais e sobre o desempenho escolar dos indivíduos. A escolha dessa variável de análise se justifica dado que já existem evidências de uma associação entre violência e desempenho escolar (GAMA; SCORZAFAVE, 2013; SEVERNINI, 2007; TEIXEIRA; KASSOUF, 2015). No entanto, não há estudos que investiguem em que medida as habilidades socioemocionais fazem a mediação dessa relação, sendo essa a principal contribuição do presente trabalho.

Utilizando dados de desempenho escolar (medido pelo SAERJINHO) e habilidades socioemocionais (medidas pelo instrumento SENNA) para alunos de $1^{\circ}$ e $3^{\circ}$ ano do ensino médio do estado do Rio de Janeiro em 2013 e registros de ocorrências de crimes no entorno das escolas, o presente estudo se propõe a examinar a associação entre a exposição à violência e as habilidades não cognitivas dos alunos, dada a hipótese de que essas últimas funcionariam como mediadoras de parte do efeito da violência sobre o desempenho escolar. 


\section{Revisão de Literatura}

Nesse capítulo, primeiramente, será discutida a importância das habilidades socioemocionais e suas origens. Em seguida, serão apresentados os estudos que relacionam tais habilidades ao desempenho escolar. Por fim, será discutida a associação entre violência e as características não cognitivas de crianças e jovens.

\subsection{Importância das Habilidades Socioemocionais}

No final do século XX foi aberto um debate para serem definidos os novos rumos que a educação mundial deveria tomar. Um dos grandes marcos desse movimento foi o relatório publicado pela UNESCO, no qual Delors et al. (1999) sugerem um sistema de ensino fundamentado em quatro grandes pilares: (i) Aprender a Conhecer, (ii) Aprender a Fazer, (iii) Aprender a Ser, e (iv) Aprender a Conviver. Assim, ao redor de todo o mundo foram tomadas iniciativas para avaliar quais seriam os melhores métodos para se alcançar os objetivos propostos e para testar se não haveriam outras finalidades do aprendizado que ainda não haviam sido explicitadas. De uma forma geral, os resultados desses estudos convergem para a ideia de que o intenso fluxo de informações do mundo contemporâneo, aliado ao advento de novas tecnologias e instituições, permitiu que surgissem novas formas de produção e interação de conhecimento muito mais flexíveis do que aquelas até então utilizadas. Assim, os alunos e professores não seriam mais meros receptores e transmissores do saber, mas precisariam desenvolver as habilidades de construir parte do conhecimento e adaptar aquele já existente às suas necessidades, além de estarem aptos a lidar com diferentes culturas e situações.

Visando examinar as mudanças conceituais em relação ao conhecimento, ensinamento e aprendizagem que estavam acontecendo nesta passagem de século, Lee (2013) destacou algumas das principais competências identificadas internacionalmente para a educação do século 21, como criatividade, inovação, comunicação, colaboração e adaptabilidade, e nota que todas estas características estão inerentemente relacionadas às soft skills, evidenciadas por Heckman e Kautz (2012). 
Apesar da importância recentemente destacada dessas características, os estudos sobre habilidades socioemocionais não são recentes. Sua origem remonta ao trabalho de Allport (1937). Buscando desenvolver um trabalho compreensivo sobre a personalidade, ele procurou identificar todos os adjetivos que poderiam descrever atributos de personalidade, como "amável" ou "agressivo", encontrando centenas destas denominações. O estudo do psicólogo estadunidense foi refinado por outros pesquisadores, como o britânico Raymond Cattell, que sintetizou a lista de adjetivos destacados por Allport e os agrupou em 35 clusters por meio de análise fatorial. Testes de personalidade foram então desenvolvidos para tentar captar as múltiplas dimensões da personalidade descobertas até então e diversos autores subsequentes concluíram que eram cinco os fatores que melhor explicavam a variação nestes testes: 1) Abertura a Novas Experiências; 2) Extroversão; 3) Amabilidade; 4) Conscienciosidade e 5) Estabilidade Emocional. Estas dimensões, através das quais a personalidade humana deveria, ser analisada ficaram conhecidas como Big Five (JOHN; SRIVASTAVA, 1999).

A seguir, são apresentadas as definições de cada um destes grupos de características socioemocionais, juntamente da descrição de Lócus de Controle, que é um sexto construto medido pelo instrumento SENNA, conforme colocado em Santos e Primi (2014):

1. Abertura a Novas Experiências: tendência a ser aberto a novas experiências estéticas, culturais e intelectuais. O indivíduo aberto a novas experiências caracteriza-se como imaginativo, artístico, excitável, curioso, aventureiro, não convencional e com amplos interesses.

2. Extroversão: orientação de interesses e energia em direção ao mundo externo e pessoas e coisas (ao invés do mundo interno da experiência subjetiva). O indivíduo extrovertido é caracterizado como amigável, sociável, autoconfiante, energético e entusiasmado.

3. Amabilidade: tendência a agir de modo cooperativo e não egoísta. O indivíduo amável ou cooperativo se caracteriza como tolerante, altruísta, modesto, simpático, não teimoso e sincero. 
4. Conscienciosidade: tendência a ser organizado, esforçado e responsável. O indivíduo consciencioso é caracterizado como eficiente, organizado, autônomo, disciplinado, não impulsivo e orientado para seus objetivos (batalhador).

5. A Estabilidade Emocional (o contrário de Neuroticismo): previsibilidade e consistência de reações emocionais, sem mudanças bruscas de humor. O indivíduo emocionalmente estável é caracterizado como despreocupado, sereno, amigável, comedido e autoconfiante. Vale observar que uma pessoa instável emocionalmente, ou seja, com alto nível de neurotisicmo, pode manifestar depressão e desordens de ansiedade.

6. Lócus de Controle: reflete em que medida indivíduos atribuem situações correntemente vividas a decisões e atitudes por eles tomadas no passado (lócus interno), ou ao acaso, sorte ou ações e decisões tomadas por terceiros (lócus externo).

\subsection{Habilidades Socioemocionais na Educação}

Uma das preocupações da literatura tem sido investigar a associação entre habilidades socioemocionais e desempenho escolar. Almlund et al. (2011) concluem que o aumento de um desvio-padrão no construto abertura a novas experiências está associado a um acréscimo de até 0,2 ano de estudo na escolaridade final atingida pelos indivíduos. Essa dimensão também está significativamente correlacionada com a média final de notas nas escolas, sendo que essa relação representa um terço da correlação estimada entre inteligência e notas (POROPAT, 2009). Lounsbury et al. (2004) verificaram que alunos do ensino médio mais abertos a novas experiências faltavam menos às aulas e optavam por cursos mais difíceis de matemática quando lhes era facultado escolher, ainda que não obtivessem ao final notas mais altas que os demais.

A conscienciosidade também se encontra bastante relacionada à escolaridade final. Lleras (2008) encontrou que indivíduos com características dessa dimensão, como pontualidade nas aulas e na entrega do dever de casa, poderiam ter sua escolaridade final prevista com até 10 anos de antecedência. Ao mesmo tempo, de seis habilidades socioemocionais analisadas, Santos e Primi (2014) constatam que conscienciosidade é a mais 
correlacionada com medidas de sucesso de aprendizado.

Por outro lado, Carneiro, Crawford e Goodman (2007) verificam que, embora a extroversão não seja tão importante para determinar as notas de testes cognitivos (pois seu efeito não parece ser monotônico), ela ajuda na decisão dos jovens de permanecerem na escola por mais tempo. A amabilidade também é relacionada positivamente à probabilidade de conclusão do ensino médio por Duncan e Magnuson (2011), enquanto a falta de estabilidade emocional na infância é relacionada negativamente a esta probabilidade pelos mesmos autores. Apesar de ajudar a prever a escolaridade final atingida, a estabilidade emocional não parece estar associado às notas e resultados de testes padronizados (SANTOS; PRIMI, 2014).

\subsection{Exposição à Violência e sua Relação com as Habilidades Socioemocionais}

A literatura apresenta evidências da relação entre violência e habilidades socioemocionais que não conversam diretamente com as características não cognitivas que serão analisadas neste trabalho. As habilidades socioemocionais analisadas são das mais variadas, tendo como alguns exemplos problemas de internalização (ansiedade, depressão, transtorno de estresse pós-traumático [PTSD]) e externalização (agressividade, hiperatividade, comportamento delinquente), além de fatores como bem estar mental, satisfação na vida e confiança nos outros. Entretanto, é possível estabelecer uma ponte de forma a aproximar as conclusões da literatura para auxiliar nessa pesquisa. Além disso, embora alguns estudos discutam que ser vítima de violência é mais grave para o psicológico de um indivíduo do que ser testemunha ou ouvir falar (PERKINS; GRAHAM-BERMANN, 2012), outros demonstram que exposição à violência indireta também possui importantes desdobramentos para o socioemocional (MARGOLIN et al., 2010). O foco aqui será na literatura que trata sobre a violência na comunidade.

Os estudos que analisam exclusivamente a exposição à violência na comunidade, como o de Hardaway, McLoyd e Wood (2012), demonstram a sólida relação que existe entre esse domínio de violência e as habilidades socioemocionais de jovens. Utilizando um índice composto por ocorrências na comunidade tanto de violência direta ("ser atacado 
por um grupo de pessoas", "ter uma faca ou arma apontada em sua direção", "ter sido cortado ou esfaqueado" e "ter levado um tiro"), quanto indireta ("ter visto alguém atirando ou esfaqueando outra pessoa") para uma amostra de adolescentes de baixa renda, investigam os potenciais efeitos moderadores de três fatores em associações entre exposição à violência e ajuste socioemocional: clima escolar, relações positivas com os pais e participação em atividades extracurriculares. Uma importante constatação é que a exposição à violência está relacionada tanto a problemas de internalização (como ansiedade e sentimento de solidão), quanto de externalização (como comportamento delinquente). Em relação aos fatores moderadores, embora o clima escolar não tenha se mostrado atenuante do efeito da violência no ajuste socioemocional dos adolescentes, altos índices de participação em atividades extracurriculares e relações positivas com os pais revelaram-se efetivos na diminuição do efeito negativo que a exposição à violência tem sobre problemas de externalização. Por outro lado, nenhum dos fatores moderadores se mostrou como intermediário na relação entre violência e problemas de internalização.

Para estimar o impacto da exposição à violência na comunidade sobre a saúde mental de crianças e adolescentes, Fowler et al. (2009) realizam uma meta análise de 114 estudos sobre o tema. O efeitos mais importantes encontrados foram relacionados ao desenvolvimento de Transtornos de Estresse Pós-Traumático (PTSD), cujos sintomas se resumem à reexperiência traumática (pesadelos e lembranças espontâneas, involuntárias e recorrentes do evento traumático), fuga e isolamento (afastamento de qualquer estímulo que possa desencadear lembranças traumáticas), distanciamento emocional (sensação de distanciamento em relação às outras pessoas, diminuição da afetividade, pessimismo quanto ao próprio futuro) e hiperexcitabilidade psíquica e psicomotora (taquicardia, sudorese, tonturas, dor de cabeça, distúrbios do sono, dificuldade de concentração, irritabilidade, hipervigilância). Esse efeito foi significativamente maior do que aqueles sobre problemas de externalização e internalização, possivelmente refletindo a frequência e cronicidade com que a violência nas comunidades ocorre. Ou seja, exposição à violência na comunidade parece representar uma forma de trauma principal que está particularmente associada com o desenvolvimento de sintomas de PTSD. Jovens que vivem em bairros vi- 
olentos podem se sentir continuamente em risco, com medo de sofrerem assaltos, roubos, espancamentos, etc. Além disso, a violência pode acabar afetando a vida de todos no bairro, e então os jovens ouvem ou presenciam atos de violência contra seus familiares, amigos e vizinhos. Isso faz com que sintam-se constantemente com medo e temam por sua segurança, assim como pela segurança daqueles que estão a sua volta (BUCKNER; BEARDSLEE; BASSUK, 2004).

Ainda na pesquisa de Fowler et al. (2009), um efeito de magnitude moderada foi encontrado entre exposição à violência e problemas de externalização (controle comportamental), o que pode ser explicado por diversas teorias. Dentre elas, a de que exposição à violência banaliza o uso de comportamentos agressivos (GUERRA; HUESMANN; SPINDLER, 2003). Além disso, estudos sugerem que exposição à violência leva tanto à hiperexcitação (hyperarousal) em momentos de descanso, quanto à hipoexcitação (hypoarousal) em momentos de exposição à violência, o que poderia contribuir para um aumento na chance de o jovem se engajar em comportamento externalizante, mesmo quando alguns dos mesmos jovens sofrem de sintomas de estresse pós-traumático (PTSD) (COOLEYQUILLE et al., 2001). Por fim, houve um efeito positivo mas de menor magnitude da exposição à violência sobre problemas de internalização. Embora o efeito seja pequeno, tem o mesmo tamanho daquele identificado para outros fatores de estresse, como o abuso sexual, por exemplo. Vale ressaltar que esse efeito menor não inclui o efeito encontrado de PTSD, o qual, como sendo uma desordem de ansiedade, poderia ser considerado como parte da categoria de problemas de internalização. Assim, examinando as magnitudes dos efeitos de PTSD e de problemas de internalização, fica claro que a exposição à violência na comunidade é um preditor bastante importante de estresse psicológico.

Fowler et al. (2009) ainda analisaram os efeitos moderadores dos tipos de violência na comunidade e da idade dos indivíduos na relação entre a exposição à violência e a existência de problemas mentais. Concluem que, quanto maior a proximidade em que ocorre a violência, maior o efeito sobre problemas de externalização (vitimização apresentou efeito maior que testemunhar atos de violência na comunidade, que por sua vez, apresentou efeito maior do que somente ouvir falar da violência). Entretanto, testemunhar e ouvir 
falar sobre violência na comunidade foi um preditor de PTSD em níveis similares ao de vitimização pessoal. Sobre as idades de cada grupo, adolescentes reportaram uma relação mais forte entre exposição à violência e problemas de externalização, enquanto crianças demonstraram maiores problemas de internalização.

Já Overstreet e Mazza (2003) realizam um estudo mais abrangente que busca auxiliar no entendimento da literatura existente sobre violência na comunidade e guiar pesquisas futuras sobre esse tema e sua relação com o desenvolvimento infantil. Apresentam a seguinte definição para violência na comunidade, retirada de Potter (1999): "Violência na comunidade é violência interpessoal que ocorre em lugares públicos." A partir de então, analisam a atuação das crianças em diversos contextos e como cada um deles impacta o desenvolvimento de sua saúde mental.

No contexto da própria criança, pesquisadores argumentam que a violência na comunidade altera a maneira como ela vê o mundo, sua habilidade de formar relacionamentos e sua habilidade de modelar a excitação. Mais especificamente, o estresse, a ansiedade e o medo gerados pela violência na comunidade podem interferir no desenvolvimento de tarefas básicas, tais como o desenvolvimento de confiança nos outros, de um senso de segurança, da regulação emocional e da exploração e domínio sobre o ambiente. Assim, para crianças que se encontram expostas à violência crônica na comunidade, o perigo, e não a segurança, pode se tornar um princípio de organização em sua vida, levando a sentimentos constantes de ameaça, desamparo e desespero, resultando, por sua vez, em problemas mentais tais como Transtornos de Estresse Pós Traumático (PTSD), depressão e agressividade. Um dos resultados trazidos pelo artigo é o de Schwab-Stone et al. (1995), os quais demonstram que testemunhar violência no último ano e se sentir inseguro estão positivamente relacionados entre si, além de ambos estarem estatisticamente relacionados a agressividade, comportamento antissocial, sentimento constante de infelicidade e desempenho acadêmico prejudicado.

Algumas evidências anedóticas ilustram essa relação entre violência e habilidades socioemocionais. Serão citados alguns casos reais encontrados em notícia de jornal online (DIA, 2015). O primeiro deles é sobre uma menina de 10 anos que "se viu no meio de um 
arrastão, em Irajá, Zona Norte do Rio, quando voltava de um aniversário no shopping na companhia das amigas da escola. Sua reação, ao ver criminosos armados, foi gritar em desespero. Durante dois anos, o trauma da violência vista da janela do carro acompanhou a pequena estudante. 'Ela não podia ouvir barulho que se assustava. Acordava no meio da noite com pesadelos e perdeu semanas de aula', conta a mãe. Ainda hoje, tem dificuldades para dormir quando há tiroteios no bairro onde mora com a família.". O segundo caso é de um menino de 12 anos que "guarda na memória os gritos de um homem sendo torturado e esquartejado por traficantes na rua em frente a sua casa, numa favela carioca dominada pelo tráfico". A notícia ainda ressalta que no mês de agosto de 2015, os confrontos nos complexos de favelas da Maré e de Manguinhos deixaram quase 40 mil estudantes sem aula na cidade. Na época da reportagem, mais de cem mil crianças estudavam nas 155 Escolas do Amanhã, localizadas em áreas conflagradas ou recém-pacificadas da cidade. Segundo o neurocientista Roberto Lent, professor do Instituto de Ciências Biomédicas da UFRJ, que contribuiu com a reportagem, "As crianças correm mais risco de adoecer porque sua imunidade fica mais baixa quando há medo (estresse) crônico, e se tornam mais vulneráveis a transtornos psicológicos e de aprendizagem, porque seu foco atencional (e emocional) fica sempre voltado para um possível evento violento que pode acontecer a qualquer momento. (...) Esse estado permanente de medo causa estado crônico nas reações que normalmente são passageiras: o ataque (agressividade) ou a fuga (depressão).”.

Dessa maneira, as evidências apontam uma relação negativa entre a exposição à violência e o desenvolvimento socioemocional de crianças e jovens, bem como uma associação entre essas habilidades e o desempenho escolar. No entanto, a literatura não analisa como as habilidades socioemocionais fazem a mediação dessa relação. Assim, este estudo pretende não só analisar quais dimensões socioemocionais são mais afetadas pela violência na comunidade, mas também se essas dimensões funcionam como mediadoras de parte do efeito da violência sobre a proficiência escolar. 


\section{Metodologia e Dados}

\subsection{Dados}

Para relacionar as notas e as habilidades socioemocionais dos estudantes do ensino médio aos indicadores de violência no arredor das escolas, foi necessário realizar a compatibilização de duas fontes de dados detalhadas a seguir.

\subsubsection{Base de Dados das Habilidades Socioemocionais}

Santos e Primi (2014) desenvolveram uma ferramenta para mensuração do nível das habilidades socioemocionais de alunos do ensino básico no Brasil. Esses dados foram coletados em outubro de 2013 e possuem informações sobre um total de 24.585 estudantes.

Além de conter os resultados do instrumento elaborado, que mensura seis construtos socioemocionais (conscienciosidade, extroversão, estabilidade emocional, locus de controle interno, amabilidade e abertura a novas experiências), a base de dados conta ainda com respostas dos estudantes a respeito de: (i) suas características individuais (sexo, idade e raça); (ii) ambiente familiar (nível de educação da mãe; se o jovem mora com a mãe; se os pais são alfabetizados; o número de livros no domicílio; se a família é beneficiária do Bolsa Família; se há calçadas, energia, água, saneamento e serviço doméstico onde vivem; quantos banheiros, refrigeradores, máquinas de lavar, DVDs, automóveis, dicionários há no domicílio e se há computador com internet no domicílio); (iii) comportamento de seus pais com relação a educação dos filhos (hábitos de leitura dos pais e dos filhos e se os pais incentivam a leitura); (iv) resultados de um teste de português e matemática realizado no segundo semestre de 2013 (SAERJINHO).

\subsubsection{Base de Dados de Violência do Instituto de Segurança Pública}

O banco de dados com variáveis de violência foi montado a partir das informações disponíveis no site do Instituto de Segurança Pública do Rio de Janeiro para os anos de 2012 e 2013, o qual fornece o registro de 39 tipos de ocorrências para o estado separadas por mês e detalhadas por Áreas Integradas de Segurança Pública (AISP) e por delegacia. Cada AISP possui uma ou mais delegacias, sendo que há um total de 39 AISPs e 139 
delegacias em todo o estado. Foi solicitada a população por delegacia ao ISP para que se pudesse calcular os índices por 100 mil habitantes. Os crimes divulgados estão classificados em cinco categorias: crimes violentos letais e intencionais, crimes violentos não letais contra a pessoa, crimes violentos contra o patrimônio, delitos de trânsito e atividade policial. Optou-se por utilizar índices formados a partir das três primeiras categorias por se acreditar que elas reflitam melhor a influência que se deseja estudar sobre as habilidades socioemocionais dos alunos nesse caso. Roubo a transeunte, por exemplo, é um dos que afetam mais diretamente os estudantes, principalmente aqueles que vão a pé para a escola. Já lesão corporal dolosa e homicídio doloso são crimes contra a vida, os quais devem ter efeitos psicológicos mais graves sobre os jovens do que crimes de trânsito. Roubos de veículos são relevantes por possuírem menor erro de medida, já que as pessoas que têm seus carros roubados precisam realizar o boletim de ocorrência para obter o ressarcimento do seguro. Além disso, esse tipo de ocorrência demonstrou alta correlação com outros delitos de interesse, como homicídio doloso, roubo a estabelecimentos comerciais, roubo a transeunte, roubo de aparelho celular e roubo em coletivos. Assim, os três índices selecionados para se trabalhar foram:

$\underline{\text { Crimes Violentos Letais e Intencionais contra a Pessoa }}$

- Homicídio Doloso

- Lesão Corporal Seguida de Morte

- Latrocínio (Roubo seguido de morte)

- Encontro de Cadáver

- Encontro de Ossada

Crimes Violentos Não Letais contra a Pessoa

- Estupro

- Lesão Corporal Dolosa

- Tentativa de Homicídio 


\section{Crimes contra o Patrimônio}

- Roubo a Estabelecimento Comercial

- Roubo a Residência

- Roubo de Veículo

- Roubo de Carga

- Roubo a Transeunte

- Roubo em Coletivo

- Roubo a Banco

- Roubo de Caixa Eletrônico

- Roubo de Aparelho Celular

- Furto de Veículos

- Extorsão Mediante Seqüestro (Sequestro Clássico)

\subsubsection{Manipulação e Compatibilização das Base de Dados}

Os dados mensais dos diferentes tipos de crimes foram somados para cada uma das delegacias a fim de formar bases anuais dos crimes ocorridos no estado do Rio de Janeiro. Visando diminuir o efeito de variações que pudessem ter ocorrido especificamente em um ou outro ano, decidiu-se trabalhar com uma média dos delitos cometidos em 2012 e 2013. Além disso, para entrar em conformidade com o padrão das estatísticas de crime divulgadas, optou-se por utilizar a taxa de ocorrências por 100 mil habitantes, e não o valor absoluto dos registros. Isso faz com que áreas maiores, que possuem proporcionalmente mais habitantes, não sejam consideradas erroneamente mais violentas só porque apresentam um número maior de registro de delitos (e vice-versa). Assim, foram calculadas as taxas por 100 mil habitantes para os anos de 2012 e 2013 e, em seguida, calculada a média entre as taxas desses anos para cada um dos delitos.

Com base na informação sobre município e bairro das escolas e das informações dos bairros de abrangência de cada delegacia, foi possível associar cada escola à area de atuação de uma delegacia.

Paralelamente, atribuíram-se às escolas da base de dados das habilidades socioemocionais suas respectivas delegacias responsáveis de acordo com o município e bairro informados. Assim, através das delegacias, foi possível ligar às escolas as informações de violência das bases de dados formadas a partir das planilhas disponibilizadas pelo ISP. 
Portanto, a base de dados utilizada nesse trabalho possui notas e características socioemocionais e familiares em nível de alunos e informações de violência agregadas por delegacia policial.

Uma hipótese importante do nosso trabalho é que os jovens vivem próximos às escolas nas quais estudam. Isso é bastante razoável dentro do sistema de alocação da rede pública estadual carioca, no qual a distribuição das vagas tem como uma das prioridades a proximidade da residência. Dessa forma, pode-se considerar a violência no entorno das escolas como uma boa proxy para a exposição à violência dos alunos que as frequentam.

\subsection{Metodologia}

Este estudo está baseado em duas análises principais. A primeira investiga a associação entre a violência reportada no entorno das escolas e as habilidades socioemocionais dos alunos que nelas estudam. A segunda avalia se há associação entre essa violência e a proficiência dos alunos e se essa associação é mediada pelas habilidades socioemocionais.

Para estudar a relação entre a violência e as habilidades socioemocionais, primeiramente, utilizou-se o método de Mínimos Quadrados Ordinários. O modelo estimado é representado pela equação, estimada separadamente para $1^{\circ}$ e $3^{\circ}$ ano do ensino médio:

$$
Y_{i e d}=\alpha+\beta X_{d}+\gamma Z_{i e d}+\epsilon_{i e d}
$$

no qual $Y_{\text {ied }}$ representa cada um dos construtos medidos para o aluno $i$ para a escola $e$ na área da delegacia $d, X$ pode representar cada um dos três índices de violência da delegacia $d$ e $Z_{i e d}$ diz respeito a um conjunto de variáveis de controle em nível do aluno.

Foram incluídas as seguintes variáveis de controle: idade; raça; sexo; se jovem mora com a mãe; escolaridade da mãe; se onde mora há calçadas, energia elétrica, água encanada, coleta de lixo, empregada doméstica, máquina de lavar e automóvel; se a família é beneficiária do Bolsa Família; se tem livros em casa e qual a quantidade; com que frequências pais lêem; se pais incentivam a leitura; com que frequência o jovem lê; e se a escola fica em zona urbana ou rural. Como os modelos foram estimados em nível de 
aluno, mas a variável de violência está agregada em nível de delegacia, os erros-padrão foram estimados por cluster de delegacias.

De forma a complementar a análise de Mínimos Quadrados Ordinários, também foram estimadas Regressões Quantílicas (KOENKER; JR, 1978). A ideia é investigar se a associação entre violência e conscienciosidade, por exemplo, é maior para os indivíduos de alta conscienciosidade do que para os alunos de baixa conscienciosidade. Optou-se por estimar as Regressões Quantílicas para os quantis 10, 25, 50, 75 e 90.

Para a análise de mediação da associação entre proficiência e violência através das habilidades socioemocionais, foi utilizada a abordagem de Equações Estruturais. Segundo Klem (1995), o SEM - Structural Equations Model pode ser visto como extensão do modelo linear de regressão múltipla, uma vez que esse se preocupa em prever uma única variável dependente enquanto aquele empenha-se em estimar uma relação com ao menos duas variáveis dependentes, sendo uma delas o mediador. A figura abaixo representa as relações com e sem mediação, respectivamente:

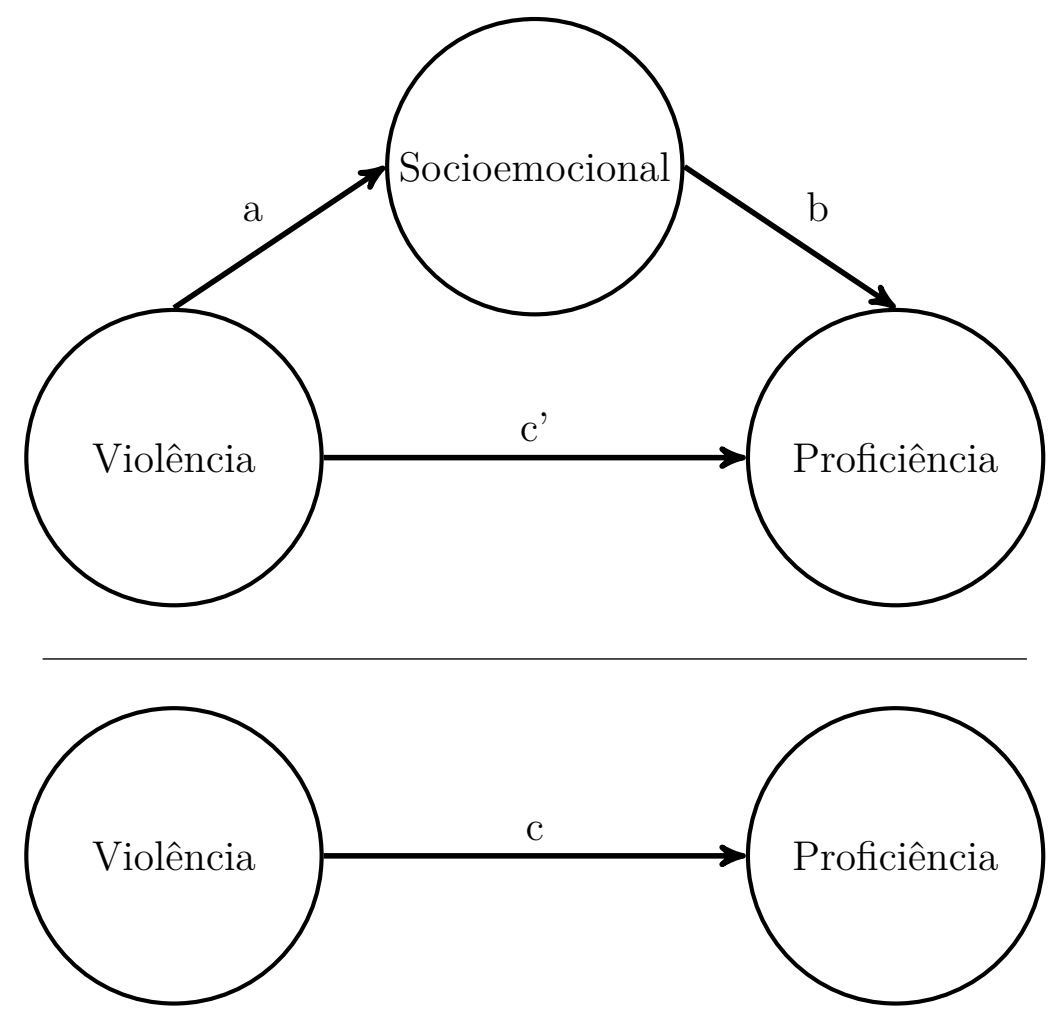

Diagrama 1: Modelo de mediação das habilidades socioemocionais na associação entre violência e desempenho acadêmico

Fonte: Elaboração própria 
No caso com mediação, a violência no entorno das escolas afeta a proficiência de duas formas. A primeira é denominada efeito direto, e está representada no diagrama pela seta $c^{\prime}$. Esse é o caso quando os jovens deixam de ir à escola em decorrência da violência nas ruas, quando há falta de profissionais interessados em lecionar em certas escolas devido ao risco que a área apresenta, ou quando a instituição fica até meses sem aulas em razão de confrontos entre policiais e bandidos na região, por exemplo. Já a segunda forma através da qual a violência pode afetar a nota dos alunos é denominada efeito indireto, e está representada no diagrama pelo produto $a b$. A influência que a violência exerce sobre o socioemocional é decorrente dos efeitos psicológicos gerados pela vivência em ambientes violentos, que faz com que os indivíduos sintam-se constantemente ameaçados ou que traz problemas relativos a estresse pós-traumático nos casos em que os jovens foram vítimas ou testemunharam situações violentas. Já a relação entre as habilidades socioemocionais e a proficiência é mais subjetiva. Uma criança com maior abertura a novas experiências, por exemplo, tende a ser mais curiosa e ter mais gosto por questionamentos. Isso interfere diretamente em sua forma de aprendizado, podendo facilitar seu interesse pelas aulas e assuntos ministrados e culminando em melhores notas nas provas.

O Modelo de Equações Estruturais utilizado é representado pelas duas equações abaixo, sendo que o conjunto de controles utilizado em ambas equações é o mesmo e a estimação é realizada por máxima verossimilhança:

$$
\begin{gathered}
Y_{i e d}=\alpha_{1}+a X_{d}+\gamma_{1} Z_{i e d}+\epsilon_{i e d} \\
W_{i e d}=\alpha_{2}+c^{\prime} X_{d}+b Y_{i e d}+\gamma_{2} Z_{i e d}+\epsilon_{i e d}
\end{gathered}
$$

no qual $Y_{i e d}$ representa cada um dos construtos medidos para o aluno $i$ para a escola $e$ na área da delegacia $d, X$ pode representar cada um dos três índices de violência da delegacia $d, Z_{i e d}$ diz respeito a um conjunto de variáveis de controle em nível do aluno e $W_{i e d}$ é a nota de matemática ou língua portuguesa do aluno no teste do SAERJINHO. 


\section{Análise Descritiva}

A tabela abaixo apresenta as taxas médias das ocorrências criminais (por 100 mil habitantes) dos anos de 2012 e 2013 consideradas no trabalho. Lesão Corporal Dolosa possui a maior média dentre eles. Roubo a transeunte, a segunda maior, demonstrando, ainda, o maior valor máximo, de 3.692,47 roubos por 100 mil habitantes. É de se esperar que esse delito atinja os estudantes de forma mais direta do que outros, uma vez que o simples fato de ir até a escola já os torna vulneráveis a roubos. O delito menos frequente é o sequestro clássico.

Tabela 1 - Crimes no Estado do Rio de Janeiro 100 mil/hab - Média entre 2012 e 2013

\begin{tabular}{lcccc}
\hline \hline Variável & Média & Desvio Padrão & Mínimo & Máximo \\
\hline Crimes Letais Intencionais & 28,89 & 17,94 & 1,67 & 90,37 \\
\hline Homicídio Doloso & 22,63 & 15,86 & 0,00 & 70,47 \\
Latrocínio & 0,79 & 0,85 & 0,00 & 3,89 \\
Lesão Corporal Seguida Morte & 0,24 & 0,61 & 0,00 & 4,52 \\
Encontro de Cadáver & 4,99 & 5,66 & 0,00 & 38,69 \\
Encontro de Ossada & 0,24 & 0,48 & 0,00 & 2,77 \\
\hline Crimes Não Letais Contra a Pessoa & 666,39 & 230,28 & 326,98 & 2062,16 \\
\hline Estupro & 38,27 & 15,87 & 11,55 & 99,29 \\
Tentativa de Homicídio & 29,78 & 20,55 & 0,00 & 115,25 \\
Lesão Corporal Dolosa & 597,34 & 216,61 & 285,04 & 1930,84 \\
\hline Crimes Contra Patrimônio & 505,48 & 666,08 & 4,54 & 4501,63 \\
\hline Sequestro Clássico & 0,04 & 0,14 & 0,00 & 0,84 \\
Roubo Banco & 0,19 & 0,62 & 0,00 & 4,86 \\
Roubo Estabelecimento & 32,67 & 26,17 & 0,00 & 178,30 \\
Roubo Residência & 8,99 & 8,33 & 0,00 & 69,89 \\
Roubo Transeunte & 284,05 & 471,07 & 0,00 & 3692,47 \\
Roubo Aparelho Celular & 27,06 & 52,05 & 0,00 & 395,33 \\
Roubo Caixa Eletrônico & 0,25 & 0,58 & 0,00 & 4,03 \\
Roubo Carga & 16,05 & 23,50 & 0,00 & 190,69 \\
Roubo Veículo & 107,65 & 127,10 & 0,00 & 542,76 \\
Roubo em Coletivo & 28,54 & 46,61 & 0.00 & 360,43 \\
\hline \hline
\end{tabular}

Nota: * Significante a 10\%; ${ }^{* *}$ Significante a $5 \%$; ** Significante a $1 \%$. Fonte: Elaboração própria com dados do ISP-RJ 2012, 2013. Estatísticas dos crimes para 135 delegacias analisadas. Obs: a delegacia 1 foi retirada da amostra por ser um outlier (DP responsável pelo centro da capital).

Já as variáveis referentes às habilidades socioemocionais estão normalizadas, com média zero e variância igual a um. Um fator que será investigado nesse estudo é se a associação entre as habilidades socioemocionais e a violência é mais forte para determinados 
subgrupos da população. Inicialmente, foi realizado um teste de diferença de médias das habilidades socioemocionais de alunos cujas mães possuem ensino médio completo contra aqueles cujas mães não possuem ensino médio completo.

Alunos cuja mãe possui ao menos ensino médio completo são mais extrovertidos, mais abertos a novas experiências e possuem locus de controle mais interno, tanto no $1^{\circ}$ quanto no $3^{\circ}$ ano do ensino médio.

Tabela 2 - Teste de Diferenças de Médias das Variáveis de Habilidades Socioemocionais por Escolaridade da Mãe

\begin{tabular}{lccl|ccc}
\hline \hline & \multicolumn{3}{c|}{$1^{\circ}$ ano EM } & \multicolumn{3}{c}{$3^{\circ}$ ano EM } \\
\cline { 2 - 7 } & Sem EM & Com EM & Diferença & Sem EM & Com EM & Diferença \\
\hline Conscienciosidade & $-0,0730$ & $-0,0726$ & 0,0005 & 0,1127 & 0,0585 & $-0,0542^{*}$ \\
Extroversão & $-0,0354$ & 0,0797 & $0,1151^{* * *}$ & 0,0134 & 0,1017 & $0,0883^{* * *}$ \\
Estab. Emocional & $-0,0172$ & $-0,0215$ & $-0,0042$ & 0,0381 & 0,0697 & 0,0316 \\
Locus Controle & $-0,0816$ & 0,0091 & $0,0907^{* * *}$ & 0,1724 & 0,2406 & $0,0682^{* *}$ \\
Amabilidade & $-0,0364$ & $-0,0020$ & $0,0343^{*}$ & 0,1019 & 0,0823 & $-0,0195$ \\
Abertura & $-0,0963$ & 0,0402 & $0,1365^{* * *}$ & 0,0681 & 0,1547 & $0,0866^{* * *}$ \\
\hline \hline
\end{tabular}

Nota: ${ }^{*}$ Significante a $10 \%$; ${ }^{* *}$ Significante a $5 \% ; * * *$ Significante a $1 \%$. Fonte: Elaboração própria com base SENNA 2013.

A tabela a seguir relata o teste de diferença de médias das variáveis socioemocionais para meninos e meninas, separados por série. Nesse caso, todas as médias são estatisticamente diferentes. Em geral, as médias são mais altas para alunos do $3^{\circ}$ ano, tanto para os meninos quanto para as meninas. Elas apresentam médias mais altas de habilidades socioemocionais do que eles, com exceção de estabilidade emocional, para o $1^{\circ}$ e $3^{\circ}$ anos do ensino médio, e de abertura a novas experiências, para o $3^{\circ}$ ano do ensino médio. 
Tabela 3 - Teste de Diferença de Médias das Variáveis de Habilidades Socioemocionais por Sexo

\begin{tabular}{lccc|ccc}
\hline \hline & \multicolumn{3}{c|}{$1^{\circ}$ ano EM } & \multicolumn{3}{c}{$3^{\circ}$ ano EM } \\
\cline { 2 - 7 } & Meninos & Meninas & Diferença & Meninos & Meninas & Diferença \\
\hline Conscienciosidade & $-0,1849$ & 0,0146 & $0,1995^{* * *}$ & $-0,0462$ & 0,1779 & $0,2241^{* * *}$ \\
Extroversao & $-0,1010$ & 0,1003 & $0,2013^{* * *}$ & 0,0036 & 0,0808 & $0,0772^{* * *}$ \\
Estab. Emocional & 0,3273 & $-0,2826$ & $-0,6098^{* * *}$ & 0,3682 & $-0,1447$ & $-0,5128^{* * *}$ \\
Locus Controle & $-0,0909$ & $-0,0081$ & $0,0828^{* * *}$ & 0,1584 & 0,2281 & $0,0697^{* *}$ \\
Amabilidade & $-0,1499$ & 0,0784 & $0,2282^{* * *}$ & 0,0297 & 0,1398 & $0,1101^{* * *}$ \\
Abertura & $-0,0639$ & $-0,0205$ & $0,0434^{* *}$ & 0,1494 & 0,0774 & $-0,0720^{* * *}$ \\
\hline \hline
\end{tabular}

Nota: * Significante a $10 \%$; ** Significante a $5 \%$; ** Significante a $1 \%$. Fonte: Elaboração própria com base SENNA 2013.

Em seguida, são apresentadas as diferenças de média para alunos que possuem proficiência de língua portuguesa abaixo ou igual ao $1^{\circ}$ quartil contra alunos que possuem proficiência igual ou acima do $4^{\circ}$ quartil. É possível notar que, para língua portuguesa, os alunos de maior proficiência têm maior conscienciosidade, são mais extrovertidos, possuem locus de controle mais interno, são mais amáveis e apresentam maior abertura a novas experiências.

Tabela 4 - Testes de Diferença de Médias das Variáveis de Habilidades Socioemocionais por Proficiência de Língua Portuguesa

\begin{tabular}{lccl|ccl}
\hline \hline & \multicolumn{3}{c|}{$1^{\circ}$ ano EM } & \multicolumn{3}{c}{$3^{\circ}$ ano EM } \\
\cline { 2 - 7 } & $1^{\circ}$ quartil & $4^{\circ}$ quartil & Diferença & $1^{\circ}$ quartil & $4^{\circ}$ quartil & Diferença \\
\hline Conscienciosidade & $-0,2161$ & 0,0201 & $0,2362^{* * *}$ & $-0,0359$ & 0,1620 & $0,1979^{* * *}$ \\
Extroversão & $-0,0393$ & 0,0197 & $0,0590^{* *}$ & 0,0018 & 0,0670 & $0,0652^{*}$ \\
Estab. Emocional & $-0,0412$ & $-0,0370$ & 0,0043 & 0,0054 & 0,0432 & 0,0379 \\
Locus Controle & $-0,2278$ & 0,0674 & $0,2952^{* * *}$ & $-0,0029$ & 0,2992 & $0,3020^{* * *}$ \\
Amabilidade & $-0,1744$ & 0,0373 & $0,2117^{* * *}$ & $-0,0605$ & 0,1379 & $0,1985^{* * *}$ \\
Abertura & $-0,2494$ & 0,1380 & $0,3875^{* * *}$ & $-0,0944$ & 0,2469 & $0,3413^{* * *}$ \\
\hline \hline
\end{tabular}

Nota: * Significante a 10\%; ** Significante a 5\%; *** Significante a 1\%. Fonte: Elaboração própria com base SENNA 2013.

A próxima tabela traz resultados análogos aos da tabela anterior, mas para as proficiências em matemática. Apesar de todas as médias serem superiores para alunos de maior proficiência, a diferença não foi estatisticamente significante para extroversão. Para alunos do $3^{\circ}$ ano, especificamente, a diferença na estabilidade emocional de alunos 
abaixo do $1^{\circ}$ quartil e acima do $4^{\circ}$ da distribuição de notas de matemática também não foi significante.

Tabela 5 - Teste de Médias das Variáveis de Habilidades Socioemocionais por Proficiência de Matemática

\begin{tabular}{lccl|ccc}
\hline \hline & \multicolumn{3}{c|}{$1^{\mathrm{o}}$ ano EM } & \multicolumn{3}{c}{$3^{\circ}$ ano EM } \\
\cline { 2 - 7 } & $1^{\mathrm{o}}$ quartil & $4^{\mathrm{o}}$ quartil & Diferença & $1^{\text {o }}$ quartil & $4^{\mathrm{o}}$ quartil & Diferença \\
\hline Conscienciosidade & $-0,1643$ & 0,0094 & $0,1738^{* * *}$ & 0,0349 & 0,1661 & $0,1312^{* * *}$ \\
Extroversão & 0,0214 & $-0,0177$ & $-0,0392$ & 0,0061 & 0,0568 & 0,0507 \\
Estab. Emocional & $-0,0970$ & 0,0275 & $0,1245^{* * *}$ & 0,0241 & 0,0452 & 0,0212 \\
Locus Controle & $-0,1196$ & 0,0245 & $0,1441^{* * *}$ & 0,1465 & 0,2445 & $0,0980^{* * *}$ \\
Amabilidade & $-0,1134$ & 0,0231 & $0,1365^{* * *}$ & 0,0390 & 0,1118 & $0,0728^{* *}$ \\
Abertura & $-0,1385$ & 0,0397 & $0,1782^{* * *}$ & $-0,0169$ & 0,2175 & $0,2344^{* * *}$ \\
\hline \hline
\end{tabular}

Considerando que as médias das habilidades socioemocionais são diferentes para os subgrupos analisados em quase todos os casos, existe uma motivação para se investigar a relação entre a violência e essas habilidades separadamente para cada um desses grupos.

A seguir, foram calculadas as correlações entre as habilidades socioemocionais, os indicadores de violência e a proficiência. As magnitudes das correlações entre as características não cognitivas e os índices de violência são pequenas. Já as correlações entre essas mesmas características e as notas são maiores. Por exemplo, alunos que moram em áreas onde os crimes contra patrimônio são maiores possuem menor proficiência. 
Tabela 6 - Correlações entre Habilidades Socioemocionais, Indicadores de Violência e Proficiências

\begin{tabular}{lccc}
\hline \hline & $\begin{array}{c}\text { Crimes Violentos } \\
\text { Letais Intencionais }\end{array}$ & $\begin{array}{c}\text { Crimes Violentos } \\
\text { Não Letais contra Pessoa }\end{array}$ & $\begin{array}{c}\text { Crimes Contra } \\
\text { Patrimônio }\end{array}$ \\
\hline Conscienciosidade & $0,0458^{* * *}$ ano do Ensino Médio & \\
Extroversão & $-0,0068$ & 0,0027 & 0,0071 \\
Estab. Emocional & 0,0071 & $-0,0236^{* * *}$ & $-0,0204^{* *}$ \\
Locus Controle & $-0,0095$ & $-0,0034$ & 0,0049 \\
Amabilidade & 0,0048 & 0,0102 & $-0,0072$ \\
Abertura & $-0,0070$ & $-0,0385^{* * *}$ & $-0,0488^{* * *}$ \\
Matemática & $-0,1020^{* * *}$ & $-0,0156^{*}$ & $-0,0243^{* * *}$ \\
Língua Port. & $-0,1131^{* * *}$ & $-0,0436^{* * *}$ & $-0,1980^{* * *}$ \\
\hline & $3^{\circ}$ ano do Ensino Médio & $-0,1930^{* * *}$ \\
\hline Conscienciosidade & $0,0194^{*}$ & $-0,0513^{* * *}$ & \\
Extroversão & $-0,0131$ & 0,0107 & $0,0189^{*}$ \\
Estab. Emocional & $0,0209^{*}$ & 0,0092 & $-0,0021$ \\
Locus Controle & $-0,0143$ & $-0,0014$ & 0,0013 \\
Amabilidade & 0,0057 & 0,0146 & $-0,0007$ \\
Abertura & $-0,0057^{*}$ & $0,0181^{*}$ & $-0,0232^{* *}$ \\
Matemática & $-0,0928^{* * *}$ & $0,0452^{* * *}$ & 0,0131 \\
Língua Port. & $-0,0760^{* * *}$ & $0,0338^{* *}$ & $-0,1824^{* * *}$ \\
\hline \hline
\end{tabular}

Nota: * Significante a $10 \%$;* Significante a $5 \%$; *** Significante a $1 \%$. Fonte: Elaboração própria com dados do ISP-RJ (2012-2013) e base SENNA 2013.

\section{Resultados}

Nesse estudo é analisada a associação entre a violência à qual os alunos do ensino médio são expostos em seu dia-a-dia, suas habilidades socioemocionais e suas notas. Uma vez que a violência impõe um clima de tensão e estresse constantes no ambiente, deveria haver um efeito prejudicial sobre os alunos por meio da deterioração de seu estado físico e psicológico. Assim, espera-se encontrar uma relação negativa entre as taxas de violência observadas no entorno da escola e o os níveis socioemocionais dos alunos, o que poderia, por fim, afetar a proficiência dos estudantes nos testes. Vale ressaltar que a principal contribuição desse trabalho não é procurar determinar se há um efeito causal, mas sim documentar a associação estudada entre esses fatores de uma forma inédita. 


\subsection{Estimações por Mínimos Quadrados Ordinários}

A partir da estimação da equação 1, a tabela 7 apresenta os coeficientes estimados da relação entre cada habilidade socioemocional e um tipo de crime. Ou seja, foram estimados 18 modelos diferentes, sendo resportados na tabela o coeficiente de interesse de cada um deles. A alteração sofrida na dimensão socioemocional representa a mudança em desvios-padrão dada uma alteração unitária na taxa de violência por 100 mil habitantes.

Tabela 7 - Relação entre Habilidades Socioemocionais e Violência - $1^{\circ}$ ano do EM

\begin{tabular}{lllllll}
\hline \hline & Consciec. & Extroversão & Est. Emoc. & Loc. Contr. & Amabilidade & Abertura \\
\hline Letais & $0,002177^{* *}$ & $-0,000443$ & 0,000787 & $-0,000510$ & 0,000356 & 0,000154 \\
Intencionais & $(0,000915)$ & $(0,000631)$ & $(0,000749)$ & $(0,000632)$ & $(0,000742)$ & $(0,000638)$ \\
Não & 0,000045 & $-0,000157^{* *}$ & $-0,000031$ & $-0,000011$ & $-0,000245^{* * *}$ & $-0,000108$ \\
Letais & $(0,000093)$ & $(0,000064)$ & $(0,000105)$ & $(0,000084)$ & $(0,000080)$ & $(0,000091)$ \\
Contra & 0,000013 & $-0,000052^{* * *}$ & $-0,000031$ & 0,000006 & $-0,000100^{* * *}$ & $-0,000063^{* * *}$ \\
Patrimônio & $(0,000029)$ & $(0,000020)$ & $(0,000034)$ & $(0,000029)$ & $(0,000025)$ & $(0,000018)$ \\
\hline \hline
\end{tabular}

Nota: * Significante a $10 \% ; * *$ Significante a $5 \% ; * *$ Significante a $1 \%$. Cada entrada dessa tabela representa o beta estimado da equação 1 que associa violência às habilidades socioemocionais. Em todos os casos, as variáveis de controle utilizadas foram: sexo; idade; raça; nível de educação da mãe; se jovem mora com a mãe; se pais são alfabetizados; número de livros no domicílio; se família recebe Bolsa Família; se há calçadas, energia, água, saneamento e serviço doméstico onde vivem; quantos banheiros, refrigeradores, máquinas de lavar, DVDs, automóveis, dicionários há no domicílio; se há computador com internet no domicílio; hábitos de leitura dos pais e dos filhos; se pais incentivam a leitura; notas de português e matemática do SAERJINHO. Os erros-padrão corrigidos por clusters de delegacias são apresentados entre parênteses. Fonte: Elaboração própria com dados do ISP-RJ (2012-2013) e base SENNA 2013.

O coeficiente estimado da relação entre conscienciosidade e crimes violentos letais e intencionais foi de 0,002177 desvios-padrão. No entanto, esse coeficiente isoladamente nos diz pouco acerca da magnitude da relação. Para deixar esse efeito mais claro, imagine que houvesse um aumento na taxa de criminalidade que levasse um aluno do percentil $25^{\circ}$ para o percentil $75^{\circ}$ da distribuição de criminalidade, o que seria um grande aumento. Isso está associado a uma mudança de apenas dois percentis na distribuição de conscienciosidade, ou seja, $25^{\circ}$ percentil da distribuição de conscienciosidade para o $27^{\circ}$ percetil. Essa relação positiva pode ser explicada pelo fato de esse construto ser medido por perguntas que tentam captar, entre outras características, organização, disciplina e diligência (interesse ou cuidado aplicado na execução de uma tarefa; zelo). Souza e Primi (2014) ainda definem a conscienciosidade como "preocupação excessiva". Assim, o fato de os jovens residirem ou frequentarem locais onde há maior ocorrência de crimes letais pode fazer com que eles 
se tornem mais cautelosos, seja por orientação dos pais ou seja por consequência do medo que sentem ao ouvir relatos de crimes ocorridos naquela área. O aumento nessa cautela pode se refletir em outros aspectos da vida além da segurança pessoal e transparecer nas atitudes em relação aos estudos, por exemplo.

A relação entre extroversão e crimes violentos não letais contra pessoa apresentou coeficiente negativo, bem como a relação dessa habilidade socioemocional com o indicador de crimes violentos contra patrimônio. A transferência de um jovem do percentil $25^{\circ}$ para o percentil $75^{\circ}$ da distribuição de crimes violentos não letais contra pessoa está associada a um deslocamento do $25^{\circ}$ percentil para o $24^{\circ}$ percentil extroversão, um efeito muito pequeno. Efeito de magnitude semelhante ocorre para o caso de crimes contra o patrimônio. Cooley-Quille, Turner e Beidel (1995) demonstram que jovens com alta exposição à violência na comunidade relatam mais medo, ansiedade, comportamentos internalizantes e experiências de vida negativas do que aqueles com baixa exposição a esse tipo de violência. Isso está de acordo com a relação negativa aqui encontrada entre violência e extroversão, uma vez que os comportamentos internalizantes são caracterizados por Hess e Falcke (2013) como tristeza e retraimento.

Amabilidade também demonstrou uma baixa associação com crimes violentos não letais contra pessoa e com crimes violentos contra patrimônio. Esse resultado corrobora a conclusão de McDonald e Richmond (2008) de que a exposição à violência na comunidade tem influência sobre sintomas da saúde mental, especialmente o da agressão, que é captado pelo inverso do construto amabilidade do SENNA.

Por último, foi encontrado um coeficiente negativo e estatisticamente significante para a relação entre abertura a novas experiências e crimes violentos contra patrimônio. A relação estimada é equivalente a fazer com que um jovem vá do $25^{\circ}$ percentil para o $22^{\circ}$ na distribuição de abertura a novas experiências se estivesse no $75^{\circ}$ percentil de crimes violentos contra patrimônio e fosse enviado para uma do $25^{\circ}$. Não há resultados na literatura sobre uma relação direta entre exposição à violência e abertura a novas experiências, mas, através da análise mais aprofundada dessa habilidade socioemocional, é possível entender porque a relação é negativa. Segundo Santos e Primi (2014), as facetas 
que compõem esse construto são: fantasia (imaginativo), estética (artístico), sensibilidade (excitável), ações (interesses amplos), ideias (curioso) e valores (não convencional). Dessa maneira, dada a forte associação relatada na literatura entre a exposição à violência e sintomas de depressão (HESS; FALCKE, 2013), é natural inferir que o jovem se torne menos excitável, interessado e curisoso, uma vez que a depressão faz com que se sinta apático, desinteressado e com menor capacidade de experimentar prazer na maior parte das atividades (PORTO, 1999). A seguir, são apresentados os resultados para os alunos do $3^{\circ}$ ano do ensino médio.

Tabela 8 - Relação entre Habilidades Socioemocionais e Violência - $3^{\circ}$ ano do EM

\begin{tabular}{lllllll}
\hline \hline & Consciec. & Extroversão & Est. Emoc. & Loc. Contr. & Amabilidade & Abertura \\
\hline Letais & 0,000464 & $-0,000718$ & 0,000905 & $-0,000990$ & 0,000461 & $-0,000354$ \\
Intencionais & $(0,000795)$ & $(0,001001)$ & $(0,000700)$ & $(0,001096)$ & $(0,000954)$ & $(0,000791)$ \\
Não & $-0,000067$ & 0,000083 & 0,000104 & $-0,000067$ & 0,000080 & 0,000127 \\
Letais & $(0,000099)$ & $(0,000112)$ & $(0,000079)$ & $(0,000075)$ & $(0,000111)$ & $(0,000089)$ \\
Contra & $-0,000018$ & $-0,000044^{*}$ & $-0,000020$ & $-0,000020$ & $-0,000079^{* * *}$ & $-0,000041^{*}$ \\
Patrimônio & $(0,000022)$ & $(0,000026)$ & $(0,000027)$ & $(0,000025)$ & $(0,000028)$ & $(0,000022)$ \\
\hline \hline
\end{tabular}

Nota: * Significante a $10 \%$; ** Significante a $5 \%$; *** Significante a $1 \%$. Cada entrada dessa tabela representa o beta estimado da equação 1 que associa violência às habilidades socioemocionais. Em todos os casos, as variáveis de controle utilizadas foram: sexo; idade; raça; nível de educação da mãe; se jovem mora com a mãe; se pais são alfabetizados; número de livros no domicílio; se família recebe Bolsa Família; se há calçadas, energia, água, saneamento e serviço doméstico onde vivem; quantos banheiros, refrigeradores, máquinas de lavar, DVDs, automóveis, dicionários há no domicílio; se há computador com internet no domicílio; hábitos de leitura dos pais e dos filhos; se pais incentivam a leitura; notas de português e matemática do SAERJINHO. Os erros-padrão corrigidos por clusters de delegacias são apresentados entre parênteses. Fonte: Elaboração própria com dados do ISP-RJ (2012-2013) e base SENNA 2013.

Ao analisar a Tabela 8, a primeira diferença que se nota em relação aos resultados do $1^{\circ}$ ano é um menor número de coeficientes estatisticamente significantes. Além disso, aqueles coeficientes que continuam estatisticamente significantes são de menor magnitude. O efeito representado pelo coeficiente da regressão de extroversão contra crimes violentos contra patrimônio é equivalente a levar um jovem do $25^{\circ}$ percentil na distribuição desse construto socioemocional para o $23^{\circ}$ percentil, caso a violência à qual ele se encontra exposto mude do $25^{\circ}$ percentil para o $75^{\circ}$. Esse mesmo impacto em relação a amabilidade equivale a fazer com que o jovem se mova do $25^{\circ}$ percentil para o $21^{\circ}$ e em relação a abertura a novas experiências é análogo a fazê-lo ir do $25^{\circ}$ percentil para o $24^{\circ}$. Esse menor número de relações estatisticamente significantes entre as habilidades socioemocionais e os índices de violência pode se dever ao fato de que, conforme os jovens passam da pré- 
adolescência para a adolescência, o egocentrismo, característicos dessa fase, pode gerar um senso artificial de segurança, levando-os a se sentirem invulneráveis à violência na comunidade (OVERSTREET; BRAUN, 2000). Outros autores defendem a ocorrência de dessensibilização (desensitization) como causa de uma responsividade emocional menor frente a uma adversidade após exposição constante a ela. Ng-Mak et al. (2004), por exemplo, demonstram que altos níveis de exposição à violência estão associados a maior agressividade, mas menor estresse psicológico de jovens, o que está em linha com relação negativa entre amabilidade e violência.

A seguir, é realizada uma análise de heterogeneidade de acordo com o nível de escolaridade das mães dos alunos.

Tabela 9 - Relação entre Habilidades Socioemocionais e Violência por Escolaridade da Mãe - $1^{\circ}$ ano do EM

\begin{tabular}{|c|c|c|c|c|c|c|}
\hline & Consciec. & Extroversão & Est. Emoc. & Loc. Contr. & Amabilidade & Abertura \\
\hline \multicolumn{7}{|c|}{ Alunos de Mães com até Ensino Médio Incompleto } \\
\hline Letais & $0.002157^{* *}$ & $-0.001415^{*}$ & 0.000840 & -0.000236 & -0.000181 & -0.000244 \\
\hline Intencionais & $(0.001002)$ & $(0.000723)$ & $(0.000876)$ & $(0.000697)$ & $(0.000783)$ & $(0.000699)$ \\
\hline Não & 0.000031 & $-0.000174^{* *}$ & -0.000141 & -0.000020 & $-0.000307^{* * *}$ & -0.000096 \\
\hline Letais & $(0.000094)$ & $(0.000071)$ & $(0.000107)$ & $(0.000096)$ & $(0.000082)$ & $(0.000095)$ \\
\hline Contra & 0.000012 & $-0.000067^{* *}$ & -0.000039 & -0.000002 & $-0.000083^{* *}$ & $-0.000063^{* * *}$ \\
\hline Patrimônio & $(0.000030)$ & $(0.000026)$ & $(0.000033)$ & $(0.000032)$ & $(0.000032)$ & $(0.000023)$ \\
\hline \multicolumn{7}{|c|}{ Alunos de Mães com pelo menos Ensino Médio Completo } \\
\hline Letais & $0.002040^{*}$ & 0.000933 & 0.000356 & -0.000721 & 0.000877 & 0.000445 \\
\hline Intencionais & $(0.001215)$ & $(0.000946)$ & $(0.001023)$ & $(0.001009)$ & $(0.001067)$ & $(0.000957)$ \\
\hline Não & 0.000041 & -0.000143 & 0.000155 & 0.000018 & -0.000163 & -0.000173 \\
\hline Letais & $(0.000125)$ & $(0.000113)$ & $(0.000151)$ & $(0.000130)$ & $(0.000143)$ & $(0.000118)$ \\
\hline Contra & 0.000001 & -0.000023 & -0.000013 & 0.000025 & $-0.000123^{* * *}$ & $0.000062^{* * *}$ \\
\hline Patrimônio & $(0.000035)$ & $(0.000032)$ & $(0.000041)$ & $(0.000033)$ & $(0.000030)$ & $(0.000022)$ \\
\hline
\end{tabular}

Nota: * Significante a $10 \%$; ${ }^{*}$ Significante a $5 \%$; ** Significante a $1 \%$. Cada entrada dessa tabela representa o beta estimado da equação 1 que associa violência às habilidades socioemocionais. Em todos os casos, as variáveis de controle utilizadas foram: sexo; idade; raça; nível de educação da mãe; se jovem mora com a mãe; se pais são alfabetizados; número de livros no domicílio; se família recebe Bolsa Família; se há calçadas, energia, água, saneamento e serviço doméstico onde vivem; quantos banheiros, refrigeradores, máquinas de lavar, DVDs, automóveis, dicionários há no domicílio; se há computador com internet no domicílio; hábitos de leitura dos pais e dos filhos; se pais incentivam a leitura; notas de português e matemática do SAERJINHO. Os erros-padrão corrigidos por clusters de delegacias são apresentados entre parênteses. Fonte: Elaboração própria com dados do ISP-RJ (2012-2013) e base SENNA 2013.

Para jovens do primeiro ano do ensino médio filhos de mães com escolaridade mais baixa, ou seja, que possuem no máximo até o ensino médio completo, é possível notar que os coeficientes do caso geral se mantém significantes. Ambos os coeficientes relativos a 
extroversão que já eram estatisticamente significantes no caso geral demonstraram magnitude absoluta superior para alunos com mães de escolaridade mais baixa e o coeficiente da relação entre crimes violentos letais intencionais e extroversão passa a ser significante ao nível de $10 \%$. Assim, os efeitos de uma elevação da violência na comunidade do $25^{\circ}$ para o $75^{\circ}$ percentil para cada um dos indicadores sobre a extroversão equivale a levar o jovem do $25^{\circ}$ percentil da distribuição dessa habilidade socioemocional para o $24^{\circ}, 24^{\circ}$ e $23^{\circ}$ percentis, respectivamente. Dessa forma, há um efeito dos crimes violentos letais intencionais sobre a extroversão do jovem que, apesar de pequeno, não aparecia como significante no caso geral. O efeito dos crimes violentos não letais contra pessoa, apesar de apresentar um coeficiente maior em termos absolutos no caso das mães com escolaridade mais baixa, demonstrou o mesmo efeito prático do caso geral. Já o coeficiente da relação entre Crimes Violentos contra Patrimônio e Extroversão foi maior em termos absolutos e capaz de mudar o impacto sobre o nível socioemocional do aluno, que no caso geral cairia para o $24^{\circ}$ percentil e no caso de mães com escolaridade mais baixa cai para o $23^{\circ}$. Os impactos sobre conscienciosidade, amabilidade e abertura a novas experiências são praticamente os mesmos reportado para o caso geral do $1^{\circ}$ ano do ensino médio. A única mudança em relação aos impactos foi que uma elevação dos crimes violentos letais contra patrimônio faz com que o aluno com mãe de baixa escolaridade vá do $25^{\circ}$ percentil para o $24^{\circ}$ percentil, e não mais para o $23^{\circ}$ como ocorria no caso geral.

Para alunos com mães de escolaridade mais alta, ou seja, com pelo menos ensino médio completo, é possível notar que diversos coeficientes deixam de ser estatisticamente significantes. Os coeficientes das relações de extroversão, que eram todos significantes no caso para alunos filhos de mães com baixa escolaridade, deixam de ser significantes no caso para mães com alta escolaridade. Além disso, um único coeficiente se mantém estatisticamente significante para as relações com o construto de amabilidade, frente a dois coeficientes no caso anterior. A relação entre conscienciosidade e crimes violentos letais intencionais passa a ser significante apenas a $10 \%$ e não mais a 5\%. Essa diminuição no número de associações relevantes entre as características não cognitivas dos alunos e a violência para filhos de mães com escolaridade mais alta indica que a escolaridade da mãe 
atua como um fator protetivo, amenizando os efeitos psicológicos da violência sobre as habilidades socioemocionais dos jovens.

Em suma, para ambos os casos não há relação entre violência e estabilidade emocional nem locus de controle interno. No caso de extroversão, só há efeito para alunos cujas mães têm até ensino médio incompleto.

A seguir, são apresentados os resultados para o $3^{\circ}$ ano do ensino médio.

Tabela 10 - Relação entre Habilidades Socioemocionais e Violência por Escolaridade da Mãe - $3^{\circ}$ ano do EM

\begin{tabular}{|c|c|c|c|c|c|c|}
\hline & Consciec. & Extroversão & Est. Emoc. & Loc. Contr. & Amabilidade & Abertura \\
\hline \multicolumn{7}{|c|}{ Alunos de Mães com até Ensino Médio Incompleto } \\
\hline Letais & 0.000354 & -0.001178 & 0.000810 & -0.000856 & -0.000024 & -0.000779 \\
\hline Intencionais & $(0.000930)$ & $(0.001181)$ & $(0.000900)$ & $(0.001149)$ & $(0.000992)$ & $(0.000981)$ \\
\hline Não & -0.000026 & 0.000148 & 0.000092 & -0.000034 & 0.000035 & $0.000208^{* *}$ \\
\hline Letais & $(0.000130)$ & $(0.000127)$ & $(0.000105)$ & $(0.000108)$ & $(0.000113)$ & $(0.000096)$ \\
\hline Contra & $-0.000049^{* *}$ & $-0.000090^{* * *}$ & 0.000007 & -0.000048 & $-0.000114^{* * *}$ & $-0.000077^{* * *}$ \\
\hline Patrimônio & $(0.000024)$ & $(0.000029)$ & $(0.000029)$ & $(0.000031)$ & $(0.000025)$ & $(0.000024)$ \\
\hline \multicolumn{7}{|c|}{ Alunos de Mães com pelo menos Ensino Médio Completo } \\
\hline Letais & 0.000703 & -0.000409 & 0.001270 & -0.000851 & 0.000786 & -0.000010 \\
\hline Intencionais & $(0.001195)$ & $(0.001145)$ & $(0.001000)$ & $(0.001370)$ & $(0.001560)$ & $(0.001116)$ \\
\hline Não & -0.000146 & -0.000053 & 0.000109 & -0.000091 & 0.000155 & -0.000013 \\
\hline Letais & $(0.000156)$ & $(0.000143)$ & $(0.000113)$ & $(0.000116)$ & $(0.000177)$ & $(0.000151)$ \\
\hline Contra & 0.000028 & 0.000008 & -0.000056 & 0.000017 & -0.000030 & 0.000001 \\
\hline Patrimônio & $(0.000040)$ & $(0.000040)$ & $(0.000040)$ & $(0.000036)$ & $(0.000056)$ & $(0.000038)$ \\
\hline
\end{tabular}

Nota: * Significante a $10 \% ;{ }^{* *}$ Significante a $5 \% ; * * *$ Significante a $1 \%$. Cada entrada dessa tabela representa o beta estimado da equação 1 que associa violência às habilidades socioemocionais. Em todos os casos, as variáveis de controle utilizadas foram: sexo; idade; raça; nível de educação da mãe; se jovem mora com a mãe; se pais são alfabetizados; número de livros no domicílio; se família recebe Bolsa Família; se há calçadas, energia, água, saneamento e serviço doméstico onde vivem; quantos banheiros, refrigeradores, máquinas de lavar, DVDs, automóveis, dicionários há no domicílio; se há computador com internet no domicílio; hábitos de leitura dos pais e dos filhos; se pais incentivam a leitura; notas de português e matemática do SAERJINHO. Os erros-padrão corrigidos por clusters de delegacias são apresentados entre parênteses. Fonte: Elaboração própria com dados do ISP-RJ (2012-2013) e base SENNA 2013.

É interessante notar que para os alunos com mães de escolaridade mais baixa há mais coeficientes estatisticamente significantes e suas magnitudes absolutas são superiores quando comparadas às do caso geral do $3^{\circ}$ ano do ensino médio, que não separa alunos por escolaridade da mãe. O efeito de se retirar um jovem de um ambiente que corresponde ao $25^{\circ}$ percentil de violência e colocá-lo em um que corresponde ao $75^{\circ}$ é semelhante àquele citado para conscienciosidade, extroversão e novas experiências, anteriormente. 
Para amabilidade, equivale a levá-lo do percentil 25 para o $18^{\circ}$. Fica claro, aqui, que ocorre maior efeito sobre a amabilidade de alunos do $3^{\circ}$ ano com mães de escolaridade mais baixa em comparação aos alunos de $1^{\circ}$ ano do ensino médio. Além disso, só foram estatisticamente significantes os coeficientes de indicadores de crimes contra patrimônio.

Entretanto, para alunos do $3^{\circ}$ ano do ensino médio com mães de escolaridade mais alta, todos os coeficientes deixam de ser estatisticamente significantes, demonstrando que podem estar agindo aqui tanto o senso de invulnerabilidade natural aos adolescentes ou a dessensibilização anteriormente citados, quanto o fator protetivo decorrente da escolaridade mais alta de suas mães. Em seguida, é feita uma análise da relação entre criminalidade no entorno das escolas e habilidades socioemocionais segregando a amostra por sexo.

Tabela 11 - Relação entre Habilidades Socioemocionais e Violência por Sexo - $1^{\circ}$ ano do $\mathrm{EM}$

\begin{tabular}{|c|c|c|c|c|c|c|}
\hline & Consciec. & Extroversão & Est. Emoc. & Loc. Contr. & Amabilidade & Abertura \\
\hline \multicolumn{7}{|c|}{ Meninos } \\
\hline Letais & $0.002543^{* * *}$ & -0.001127 & 0.000302 & 0.000392 & -0.000652 & -0.000358 \\
\hline Intencionais & $(0.000825)$ & $(0.000996)$ & $(0.000838)$ & $(0.000759)$ & $(0.001066)$ & $(0.001154)$ \\
\hline Não & 0.000076 & -0.000149 & -0.000015 & -0.000121 & $-0.000250^{* *}$ & -0.000068 \\
\hline Letais & $(0.000100)$ & $(0.000092)$ & $(0.000111)$ & $(0.000085)$ & $(0.000113)$ & $(0.000116)$ \\
\hline Contra & 0.000019 & -0.000047 & -0.000008 & -0.000009 & $-0.000096^{* *}$ & $-0.000080^{* * *}$ \\
\hline Patrimônio & $(0.000027)$ & $(0.000034)$ & $(0.000035)$ & $(0.000035)$ & $(0.000037)$ & $(0.000026)$ \\
\hline \multicolumn{7}{|c|}{ Meninas } \\
\hline Letais & 0.001796 & -0.000029 & 0.001055 & $-0.001342^{*}$ & 0.001068 & 0.000553 \\
\hline Intencionais & $(0.001291)$ & $(0.000691)$ & $(0.001076)$ & $(0.000803)$ & $(0.000947)$ & $(0.000784)$ \\
\hline Não & 0.000016 & $-0.000158^{* *}$ & -0.000049 & 0.000073 & $-0.000235^{* *}$ & -0.000132 \\
\hline Letais & $(0.000128)$ & $(0.000075)$ & $(0.000123)$ & $(0.000128)$ & $(0.000100)$ & $(0.000117)$ \\
\hline Contra & 0.000007 & $-0.000060^{* *}$ & -0.000047 & 0.000021 & $-0.000102^{* * *}$ & $-0.000047^{* *}$ \\
\hline Patrimônio & $(0.000038)$ & $(0.000024)$ & $(0.000039)$ & $(0.000034)$ & $(0.000026)$ & $(0.000023)$ \\
\hline
\end{tabular}

Nota: * Significante a $10 \%$; ** Significante a $5 \%$; $* * *$ Significante a $1 \%$. Cada entrada dessa tabela representa o beta estimado da equação 1 que associa violência às habilidades socioemocionais. Em todos os casos, as variáveis de controle utilizadas foram: sexo; idade; raça; nível de educação da mãe; se jovem mora com a mãe; se pais são alfabetizados; número de livros no domicílio; se família recebe Bolsa Família; se há calçadas, energia, água, saneamento e serviço doméstico onde vivem; quantos banheiros, refrigeradores, máquinas de lavar, DVDs, automóveis, dicionários há no domicílio; se há computador com internet no domicílio; hábitos de leitura dos pais e dos filhos; se pais incentivam a leitura; notas de português e matemática do SAERJINHO. Os erros-padrão corrigidos por clusters de delegacias são apresentados entre parênteses. Fonte: Elaboração própria com dados do ISP-RJ (2012-2013) e base SENNA 2013.

Uma diferença que se nota em relação ao caso geral (com alunos de ambos os sexos) é que o coeficiente da relação entre conscienciosidade e crimes letais intencionais 
se torna altamente significante no caso dos meninos. O efeito de levar um jovem de um ambiente do $25^{\circ}$ percentil de crimes violentos letais intencionais para um do $75^{\circ}$ equivale a fazer com que ele se mova do $25^{\circ}$ percentil na distribuição de conscienciosidade para o $27^{\circ}$ percentil. Já os coeficientes das relações entre criminalidade e extroversão deixam de ser estatisticamente significantes. Um aumento semelhante nos crimes não letais contra pessoa ou nos crimes violentos contra patrimônio é capaz de leva o aluno do $25^{\circ}$ percentil de amabilidade para $23^{\circ}$. Em relação a abertura a novas experiências, o coeficiente significante representa um impacto equivalente a levar um jovem do $25^{\circ}$ percentil para o $22^{\circ}$ no caso de um aumento nos crimes violentos contra patrimônio.

Ao analisar os resultados das regressões para meninas e compará-los ao dos meninos do $1^{\circ}$ ano do ensino médio, é possível notar que a relação entre conscienciosidade e crimes violentos letais intencionais deixa de ser estatisticamente significantes, sugerindo que os meninos são mais influenciados através da violência em relação a essa habilidade não cognitiva. Para as meninas, além das relações negativas entre os índices de criminalidade e extroversão, também aparece uma associação negativa entre lócus de controle interno e violência, indicando que estar em um ambiente com mais crimes violentos letais intencionais pode fazer com que as meninas se sintam com menor controle sobre suas próprias vidas, atribuindo situações correntemente vividas ao acaso, sorte ou ações e decisões tomadas por terceiros, segundo definição de lócus de controle externo de Santos e Primi (2014). O impacto captado pelo coeficiente da regressão entre crimes não letais contra pessoa e extroversão é suficiente para mover um aluno do $1^{\circ}$ ano do ensino médio ao longo de dois percentis. Já o coeficiente de crimes violentos contra patrimônio é suficiente para fazê-lo descer do $25^{\circ}$ até o $20^{\circ}$ percentil. Os coeficientes dos demais construtos demonstram efeitos semelhantes aos já reportados anteriormente. A seguir, são demonstrados os resultados para meninos e meninas do $3^{\circ}$ ano do ensino médio. 
Tabela 12 - Relação entre Habilidades Socioemocionais e Violência por Sexo - $3^{\circ}$ ano do $\mathrm{EM}$

\begin{tabular}{|c|c|c|c|c|c|c|}
\hline & Consciec. & Extroversão & Est. Emoc. & Loc. Contr. & Amabilidade & Abertura \\
\hline \multicolumn{7}{|c|}{ Meninos } \\
\hline Letais & 0.000462 & -0.001002 & -0.000114 & -0.001688 & 0.001286 & -0.000736 \\
\hline Intencionais & $(0.001187)$ & $(0.001307)$ & $(0.001300)$ & $(0.001587)$ & $(0.001326)$ & $(0.001188)$ \\
\hline Não & 0.000102 & 0.000071 & 0.000205 & 0.000180 & 0.000158 & 0.000188 \\
\hline Letais & $(0.000159)$ & $(0.000139)$ & $(0.000167)$ & $(0.000156)$ & $(0.000175)$ & $(0.000152)$ \\
\hline Contra & -0.000041 & -0.000024 & -0.000048 & -0.000042 & $-0.000083^{* *}$ & -0.000037 \\
\hline Patrimônio & $(0.000031)$ & $(0.000035)$ & $(0.000048)$ & $(0.000036)$ & $(0.000035)$ & $(0.000033)$ \\
\hline
\end{tabular}

\begin{tabular}{lllllll}
\hline \multicolumn{7}{c}{ Meninas } \\
\hline Letais & 0.000384 & -0.000466 & $0.001506^{*}$ & -0.000652 & 0.000062 & -0.000132 \\
Intencionais & $(0.000950)$ & $(0.001148)$ & $(0.000881)$ & $(0.001202)$ & $(0.001037)$ & $(0.000881)$ \\
Não & -0.000153 & 0.000103 & 0.000060 & $-0.000203^{*}$ & 0.000049 & 0.000106 \\
Letais & $(0.000116)$ & $(0.000143)$ & $(0.000103)$ & $(0.000112)$ & $(0.000120)$ & $(0.000096)$ \\
Contra & -0.000005 & -0.000055 & -0.000005 & -0.000011 & $-0.000077^{* *}$ & -0.000044 \\
Patrimônio & $(0.000030)$ & $(0.000035)$ & $(0.000028)$ & $(0.000039)$ & $(0.000034)$ & $(0.000028)$ \\
\hline \hline
\end{tabular}

Nota: * Significante a $10 \%$; ${ }^{*}$ Significante a $5 \%$; $* *$ Significante a $1 \%$. Cada entrada dessa tabela representa o beta estimado da equação 1 que associa violência às habilidades socioemocionais. Em todos os casos, as variáveis de controle utilizadas foram: sexo; idade; raça; nível de educação da mãe; se jovem mora com a mãe; se pais são alfabetizados; número de livros no domicílio; se família recebe Bolsa Família; se há calçadas, energia, água, saneamento e serviço doméstico onde vivem; quantos banheiros, refrigeradores, máquinas de lavar, DVDs, automóveis, dicionários há no domicílio; se há computador com internet no domicílio; hábitos de leitura dos pais e dos filhos; se pais incentivam a leitura; notas de português e matemática do SAERJINHO. Os erros-padrão corrigidos por clusters de delegacias são apresentados entre parênteses. Fonte: Elaboração própria com dados do ISP-RJ (2012-2013) e base SENNA 2013.

Para os meninos do $3^{\circ}$ ano, a única regressão que ainda apresenta coeficiente estatisticamente significante é aquela que associa amabilidade e crimes violentos contra patrimônio. Ainda assim, a magnitude do coeficiente é um pouco inferior àquela encontrada para os meninos do $1^{\circ}$ ano do ensino médio. O impacto de se levar um jovem do $3^{\circ}$ ano de uma escola em área correspondente ao $25^{\circ}$ percentil de crimes violentos contra patrimônio para uma escola em área correspondente ao $75^{\circ}$ é suficiente para fazê-lo ir do $25^{\circ}$ para o $21^{\circ}$ percentil de amabilidade.

Para as meninas do $3^{\circ}$ ano do ensino médio, é possível notar um coeficiente negativo de magnitude semelhante ao caso dos meninos para a relação entre amabilidade e crimes violentos contra patrimônio. O efeito de um aumento nesse tipo de violência do $25^{\circ}$ para o $75^{\circ}$ percentil também é o mesmo que para os meninos, fazendo com que um jovem do $3^{\circ}$ ano desça do $25^{\circ}$ percentil de amabilidade para o $21^{\circ}$. Entretanto, também há coeficientes 
significantes relativos à estabilidade emocional e lócus de controle para elas, aquele sendo positivo, com impacto suficiente para levar uma estudante do $25^{\circ}$ percentil para o $27^{\circ}$ e esse negativo, com efeito capaz de levá-la do $25^{\circ}$ para o $22^{\circ}$ percentil. Isso indica que, para o $3^{\circ}$ ano, de uma forma geral, o impacto da violência sobre as habilidades não cognitivas é maior para as meninas. Na próximas tabelas, são analisadas as relações entre violência e habilidades socioemocionais de acordo com a proficiência em língua portuguesa e matemática dos alunos. 
Tabela 13 - Relação entre Habilidades Socioemocionais e Violência por Proficiência - $1^{\circ}$ ano do EM

\begin{tabular}{|c|c|c|c|c|c|c|}
\hline & Consciec. & Extroversão & Est. Emoc. & Loc. Contr. & Amabilidade & Abertura \\
\hline \multicolumn{7}{|c|}{ Alunos de Baixa Proficiência em Língua Portuguesa } \\
\hline Letais & $0.003283^{* * *}$ & 0.001015 & 0.000627 & 0.001555 & $0.003565^{* *}$ & $0.002699^{* * *}$ \\
\hline Intencionais & $(0.001193)$ & $(0.001082)$ & $(0.001227)$ & $(0.000974)$ & $(0.001388)$ & $(0.000796)$ \\
\hline Não & 0.000162 & $-0.000249^{* *}$ & -0.000104 & 0.000059 & -0.000207 & 0.000041 \\
\hline Letais & $(0.000115)$ & $(0.000111)$ & $(0.000117)$ & $(0.000096)$ & $(0.000144)$ & $(0.000118)$ \\
\hline Contra & -0.000006 & -0.000017 & -0.000048 & 0.000027 & $-0.000070^{* *}$ & -0.000009 \\
\hline Patrimônio & $(0.000032)$ & $(0.000032)$ & $(0.000035)$ & $(0.000026)$ & $(0.000035)$ & $(0.000035)$ \\
\hline \multicolumn{7}{|c|}{ Alunos de Alta Proficiência em Língua Portuguesa } \\
\hline Letais & 0.001987 & -0.000834 & 0.001530 & 0.000607 & -0.000140 & -0.000667 \\
\hline Intencionais & $(0.001203)$ & $(0.000977)$ & $(0.000998)$ & $(0.000959)$ & $(0.001068)$ & $(0.001095)$ \\
\hline Não & 0.000009 & -0.000114 & 0.000123 & -0.000007 & -0.000096 & -0.000201 \\
\hline Letais & $(0.000182)$ & $(0.000117)$ & $(0.000179)$ & $(0.000162)$ & $(0.000164)$ & $(0.000140)$ \\
\hline Contra & -0.000025 & $-0.000050^{*}$ & 0.000010 & 0.000012 & $-0.000135^{* * *}$ & $-0.000094^{* * *}$ \\
\hline Patrimônio & $(0.000045)$ & $(0.000027)$ & $(0.000047)$ & $(0.000043)$ & $(0.000036)$ & $(0.000025)$ \\
\hline \multicolumn{7}{|c|}{ Alunos de Baixa Proficiência em Matemática } \\
\hline Letais & $0.002772^{*}$ & 0.001329 & 0.000732 & -0.000350 & 0.001563 & $0.002090^{*}$ \\
\hline Intencionais & $(0.001426)$ & $(0.001202)$ & $(0.001389)$ & $(0.001294)$ & $(0.001725)$ & $(0.001179)$ \\
\hline Não & -0.000061 & $-0.000329^{* *}$ & -0.000168 & -0.000122 & $-0.000518^{* * *}$ & -0.000210 \\
\hline Letais & $(0.000151)$ & $(0.000146)$ & $(0.000178)$ & $(0.000147)$ & $(0.000183)$ & $(0.000166)$ \\
\hline Contra & 0.000006 & $-0.000100^{* * *}$ & -0.000065 & 0.000030 & $-0.000181^{* * *}$ & $-0.000055^{*}$ \\
\hline Patrimônio & $(0.000042)$ & $(0.000036)$ & $(0.000049)$ & $(0.000036)$ & $(0.000047)$ & $(0.000033)$ \\
\hline \multicolumn{7}{|c|}{ Alunos de Alta Proficiência em Matemática } \\
\hline Letais & $0.001960^{*}$ & -0.001012 & 0.000760 & -0.000656 & -0.001595 & -0.000682 \\
\hline Intencionais & $(0.001108)$ & $(0.000904)$ & $(0.001055)$ & $(0.000899)$ & $(0.001125)$ & $(0.000986)$ \\
\hline Não & 0.000109 & 0.000038 & -0.000016 & 0.000094 & -0.000241 & -0.000032 \\
\hline Letais & $(0.000188)$ & $(0.000123)$ & $(0.000158)$ & $(0.000159)$ & $(0.000151)$ & $(0.000124)$ \\
\hline Contra & -0.000022 & -0.000017 & -0.000015 & 0.000013 & $-0.000120^{* *}$ & $-0.000072^{* * *}$ \\
\hline Patrimônio & $(0.000045)$ & $(0.000038)$ & $(0.000048)$ & $(0.000046)$ & $(0.000046)$ & $(0.000026)$ \\
\hline
\end{tabular}

Nota: * Significante a $10 \% ;{ }^{* *}$ Significante a $5 \% ;{ }^{* * *}$ Significante a $1 \%$. Cada entrada dessa tabela representa o beta estimado da equação 1 que associa violência às habilidades socioemocionais. Em todos os casos, as variáveis de controle utilizadas foram: sexo; idade; raça; nível de educação da mãe; se jovem mora com a mãe; se pais são alfabetizados; número de livros no domicílio; se família recebe Bolsa Família; se há calçadas, energia, água, saneamento e serviço doméstico onde vivem; quantos banheiros, refrigeradores, máquinas de lavar, DVDs, automóveis, dicionários há no domicílio; se há computador com internet no domicílio; hábitos de leitura dos pais e dos filhos; se pais incentivam a leitura; notas de português e matemática do SAERJINHO. Os erros-padrão corrigidos por clusters de delegacias são apresentados entre parênteses. Fonte: Elaboração própria com dados do ISP-RJ (2012-2013) e base SENNA 2013.

Foram considerados alunos de baixa proficiência aqueles que obtiveram notas iguais ou abaixo às do $25^{\circ}$ percentil da distribuição de notas de língua portuguesa. Observando os resultados para esses alunos, é possível notar que o coeficiente positivo da relação entre conscienciosidade e crimes violentos letais intencionais é o maior em valor absoluto para 
todos os casos analisados até agora, indicando que um aumento do $25^{\circ}$ percentil para o $75^{\circ}$ nesse tipo de crime faz com que um aluno do $1^{\circ}$ ano do ensino médio suba na distribuição dessa habilidade socioemocional do $25^{\circ}$ percentil para o $30^{\circ}$. Já o coeficiente da relação entre extroversão e crimes violento não letais contra pessoa equivale a um salto de apenas um percentil para baixo. Aparece aqui, pela primeira vez, um coeficiente positivo para a relação entre amabilidade e crimes violentos letais intencionais, indicando que uma maior ocorrência desse tipo de crime faria com que o jovem se tornasse mais amável, indo do $25^{\circ}$ percentil na distribuição desse construto para o $27^{\circ}$. Entretanto, o coeficiente continua negativo para a relação entre essa mesma habilidade socioemocional e crimes violentos contra patrimônio, capaz de levar um jovem do $25^{\circ}$ percentil para o $23^{\circ}$ percentil. Para abertura a novas experiências e crimes violentos letais intencionais também há uma relação positiva que faz com que o jovem suba um percentil na distribuição desse construto, indo do $25^{\circ}$ para o $26^{\circ}$

Para os alunos de alta proficiência em língua portuguesa, aqueles com notas iguais ou superiores às do $75^{\circ}$ percentil de distribuição dessas proficiências, há menos coeficientes estatisticamente significantes do que aqueles para os alunos de baixa proficiência com efeitos práticos iguais ou menores.

Para os alunos do $1^{\circ}$ ano do ensino médio com baixa proficiência em matemática, é possível notar diversas relações estatisticamente significantes, a maioria com efeitos próximos dos já citados anteriormente, em torno de dois percentis de diferença. O único efeito que se destacou foi aquele de um aumento sobre crimes violentos contra patrimônio, que faz com que o estudante desça do $25^{\circ}$ para o $17^{\circ}$ percentil de extroversão, um impacto bastante alto se comparado aos que foram analisados até agora.

Já para os alunos de alta proficiência em matemática, poucas relações entre violência e habilidades socioemocionais se mantêm estatisticamente significantes. Aquela entre crimes violentos letais intencionais aparece com coeficiente menor, mas mesmo efeito prático do caso para alunos de baixa proficiência, sendo responsável por uma mudança do aluno do $25^{\circ}$ percentil para o $27^{\circ}$. Já o impacto em amabilidade continua consistente com os casos analisados anteriormente e leva o jovem do $25^{\circ}$ para o $23^{\circ}$ percentil desse 
construto. Para abertura a novas experiências, essa queda acontece do $25^{\circ}$ percentil para $22^{\circ}$. Assim, pode-se concluir que alunos do $1^{\circ}$ ano de alta proficiência em matemática estão menos suscetíveis às influências da violência nas redondezas da escola do que aqueles de baixa proficiência em matemática.

Em seguida, são analisados os mesmos resultados, mas para jovens do $3^{\circ}$ ano do ensino médio. 
Tabela 14 - Relação entre Habilidades Socioemocionais e Violência por Proficiência - $3^{\circ}$ ano do EM

\begin{tabular}{|c|c|c|c|c|c|c|}
\hline & Consciec. & Extroversão & Est. Emoc. & Loc. Contr. & Amabilidade & Abertura \\
\hline \multicolumn{7}{|c|}{ Alunos de Baixa Proficiência em Língua Portuguesa } \\
\hline Letais & -0.000047 & -0.000244 & -0.000268 & $-0.002720^{*}$ & -0.000767 & -0.001752 \\
\hline Intencionais & $(0.001773)$ & $(0.001646)$ & $(0.001424)$ & $(0.001487)$ & $(0.001441)$ & $(0.001284)$ \\
\hline Não & -0.000059 & 0.000010 & -0.000221 & $-0.000375^{* * *}$ & -0.000023 & 0.000132 \\
\hline Letais & $(0.000143)$ & $(0.000192)$ & $(0.000143)$ & $(0.000127)$ & $(0.000150)$ & $(0.000140)$ \\
\hline Contra & -0.000017 & -0.000037 & -0.000020 & -0.000014 & $-0.000073^{*}$ & -0.000061 \\
\hline Patrimônio & $(0.000050)$ & $(0.000055)$ & $(0.000044)$ & $(0.000039)$ & $(0.000037)$ & $(0.000043)$ \\
\hline \multicolumn{7}{|c|}{ Alunos de Alta Proficiência em Língua Portuguesa } \\
\hline Letais & 0.000618 & -0.000930 & $0.002381^{* *}$ & 0.000700 & 0.001446 & 0.001018 \\
\hline Intencionais & $(0.001331)$ & $(0.001606)$ & $(0.001149)$ & $(0.001793)$ & $(0.001701)$ & $(0.001164)$ \\
\hline Não & -0.000125 & $0.000260^{*}$ & $0.000270^{* *}$ & 0.000060 & 0.000174 & 0.000052 \\
\hline Letais & $(0.000130)$ & $(0.000148)$ & $(0.000132)$ & $(0.000136)$ & $(0.000159)$ & $(0.000123)$ \\
\hline Contra & -0.000030 & -0.000056 & -0.000016 & -0.000015 & $-0.000091^{* *}$ & 0.000000 \\
\hline Patrimônio & $(0.000042)$ & $(0.000057)$ & $(0.000043)$ & $(0.000049)$ & $(0.000038)$ & $(0.000033)$ \\
\hline \multicolumn{7}{|c|}{ Alunos de Baixa Proficiência em Matemática } \\
\hline Letais & -0.000069 & $-0.002831^{* *}$ & 0.001247 & -0.002678 & -0.001280 & -0.001243 \\
\hline Intencionais & $(0.001414)$ & $(0.001160)$ & $(0.001438)$ & $(0.001622)$ & $(0.001466)$ & $(0.001206)$ \\
\hline Não & 0.000115 & 0.000198 & 0.000142 & -0.000217 & 0.000088 & $0.000335^{* * *}$ \\
\hline Letais & $(0.000131)$ & $(0.000157)$ & $(0.000170)$ & $(0.000135)$ & $(0.000109)$ & $(0.000125)$ \\
\hline Contra & 0.000007 & -0.000067 & 0.000000 & 0.000006 & -0.000028 & -0.000036 \\
\hline Patrimônio & $(0.000046)$ & $(0.000043)$ & $(0.000059)$ & $(0.000042)$ & $(0.000033)$ & $(0.000033)$ \\
\hline \multicolumn{7}{|c|}{ Alunos de Alta Proficiência em Matemática } \\
\hline Letais & 0.001657 & 0.000297 & 0.001756 & -0.000178 & 0.000812 & -0.000175 \\
\hline Intencionais & $(0.001565)$ & $(0.001895)$ & $(0.001463)$ & $(0.001614)$ & $(0.001661)$ & $(0.001260)$ \\
\hline Não & -0.000185 & 0.000335 & 0.000138 & -0.000112 & 0.000016 & 0.000136 \\
\hline Letais & $(0.000188)$ & $(0.000231)$ & $(0.000154)$ & $(0.000164)$ & $(0.000196)$ & $(0.000171)$ \\
\hline Contra & $-0.000110^{* *}$ & 0.000010 & -0.000017 & -0.000043 & $-0.000131^{* * *}$ & -0.000031 \\
\hline Patrimônio & $(0.000053)$ & $(0.000050)$ & $(0.000048)$ & $(0.000054)$ & $(0.000041)$ & $(0.000042)$ \\
\hline
\end{tabular}

Nota: * Significante a $10 \% ;{ }^{* *}$ Significante a $5 \% ; * * *$ Significante a $1 \%$. Cada entrada dessa tabela representa o beta estimado da equação 1 que associa violência às habilidades socioemocionais. Em todos os casos, as variáveis de controle utilizadas foram: sexo; idade; raça; nível de educação da mãe; se jovem mora com a mãe; se pais são alfabetizados; número de livros no domicílio; se família recebe Bolsa Família; se há calçadas, energia, água, saneamento e serviço doméstico onde vivem; quantos banheiros, refrigeradores, máquinas de lavar, DVDs, automóveis, dicionários há no domicílio; se há computador com internet no domicílio; hábitos de leitura dos pais e dos filhos; se pais incentivam a leitura; notas de português e matemática do SAERJINHO. Os erros-padrão corrigidos por clusters de delegacias são apresentados entre parênteses. Fonte: Elaboração própria com dados do ISP-RJ (2012-2013) e base SENNA 2013.

Para jovens do $3^{\circ}$ ano do ensino médio de baixa proficiência em língua portuguesa, destacam-se os impactos negativos sobre o locus de controle interno, indicando que um aumento do $25^{\circ}$ para o $75^{\circ}$ percentil tanto em crimes violentos letais intencionais quanto em crimes violentos não letais contra pessoa leva o jovem do percentil $25^{\circ}$ para o $21^{\circ}$ 
na distribuição dessa habilidade socioemocional. Um aumento equivalente no número de crimes violentos contra patrimônio faz com que um jovem do $3^{\circ}$ ano do ensino médio tenha sua amabilidade reduzida do $25^{\circ}$ percentil para o $21^{\circ}$. Esse é um resultado consideravelmente diferente do encontrado para alunos do $1^{\circ}$ ano, uma vez que não havia relações significativas para locus de controle, mas as que havia para conscienciosidade, extroversão e abertura a novas experiências não aparecem aqui.

Para alunos de alta proficiência em língua portuguesa, nota-se, além do resultado negativo para a relação entre crimes violentos contra patrimônio e amabilidade, que esteve presente tanto nas estimações de alunos de baixa proficiência do $3^{\circ}$ ano quanto dos alunos de baixa e alta proficiência do $1^{\circ}$ ano do ensino médio, dois coeficientes estatisticamente significantes e positivos para estabilidade emocional, indicando que um aumento da criminalidade poderia fazer com que esses alunos se tornasse emocionalmente mais estáveis. Esse aumento é considerável, sendo capaz de levar os estudantes do $25^{\circ}$ para o $28^{\circ}$ percentil no caso do segundo indicador e do $25^{\circ}$ para o $27^{\circ}$ no caso do terceiro.

Para os alunos do $3^{\circ}$ ano de baixa proficiência em matemática, os resultados mostram um impacto negativo sobre extroversão significante apenas para um aumento nos crimes violentos letais intencionais, suficiente para fazer com que o aluno desça do $25^{\circ}$ percentil na distribuição dessa habilidade socioemocional para o $23^{\circ}$. Já o efeito encontrado sobre abertura a novas experiências é positivo e faz com que um aluno do $3^{\circ}$ ano vá do $25^{\circ}$ percentil para o $28^{\circ}$.

Assim como para os alunos do $3^{\circ}$ ano do ensino médio de baixa proficiência em matemática, o resultado das regressões para os alunos de alta proficiência também apresentou dois coeficientes estatisticamente significantes. Entretanto, para habilidades socioemocionais distintas. Nesse caso, é encontrado um efeito negativo do aumento de crimes violentos contra patrimônio sobre conscienciosidade capaz de fazer com que o jovem desça do $25^{\circ}$ percentil para o $21^{\circ}$. O segundo coeficiente estatisticamente significante foi para a regressão entre amabilidade e o mesmo índice de violência, indicando um impacto que leva um jovem do $25^{\circ}$ percentil ao $21^{\circ}$. 


\subsection{Gráficos das Regressões Quantílicas}

Se a associação negativa entre habilidade socioemocional e violência é maior para alunos que possuem baixa amabilidade, por exemplo, isso pode estar aumentando as diferenças entre esse grupo de alunos e os demais. Para investigar se esse tipo fenômeno acontece na população estudada, foram estimadas regressões quantílicas para os percentis 10, 25, 50, 75 e 90 da distribuição de habilidades socioemocionais. Serão reportados aqui apenas os casos mais interessantes. A linha reta representa o coeficiente da estimação realizada por Mínimos Quadrados Ordinários, enquanto a outra linha representa o coeficiente das Regressões Quantílicas e a área cinza, seu intervalo de confiança.

Observando o gráfico da regressão quantílica de conscienciosidade e crimes violentos não letais, o coeficiente é significante e positivo para alunos que se encontram no primeiro decil, zero para aqueles que estão no meio da distribuição e significante e negativo para aqueles no último decil. Assim, alunos no $10^{\circ}$ percentil estariam sofrendo um pequeno impacto positivo em sua conscienciosidade, enquanto alunos de maior conscienciosidade, no $90^{\circ}$ percentil, estariam sofrendo impacto negativo. Esse mecanismo faria com que a disparidade de nível socioemocional entre os alunos diminuísse ao invés de aumentar. Entretanto, o efeito prático só é considerável para os estudantes de conscienciosidade mais alta e, ainda assim, pequeno: enquanto os jovens do $10^{\circ}$ percentil não mudam de posição com um aumento do $25^{\circ}$ para o $75^{\circ}$ percentil de crimes violentos não letais, os jovens do $90^{\circ}$ percentil descem para o $88^{\circ}$ na distribuição de conscienciosidade.

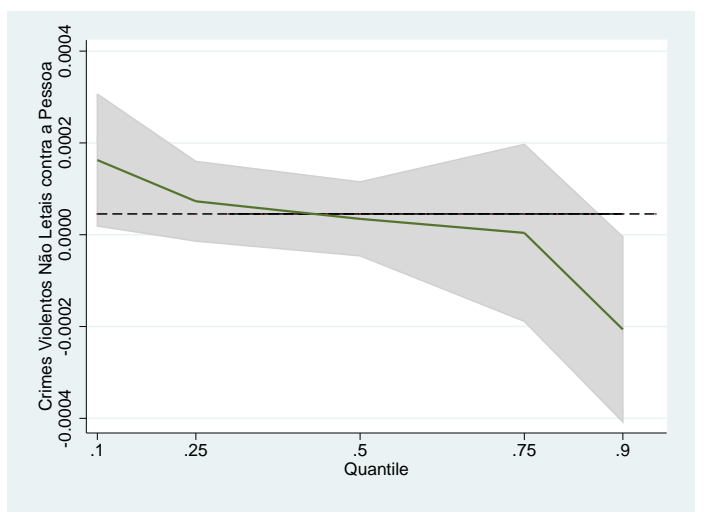

Figura 1 - Gráfico dos Coeficientes da Regressão Quantílica de Conscienciosidade e Crimes Violentos Não Letais - $1^{\circ}$ ano do EM 
Um fenômeno contrário ocorre para a relação entre estabilidade emocional e crimes violentos contra patrimônio. Os estudantes no percentil mais baixo analisado estão sofrendo com efeito negativo da violência, se tornando ainda mais instáveis emocionalmente, enquanto aqueles que estão na parte superior da distribuição estão se tornando ainda mais estáveis emocionalmente em razão dessa exposição à violência. Contudo, assim como nos casos anteriores, os efeitos são bastante baixos.

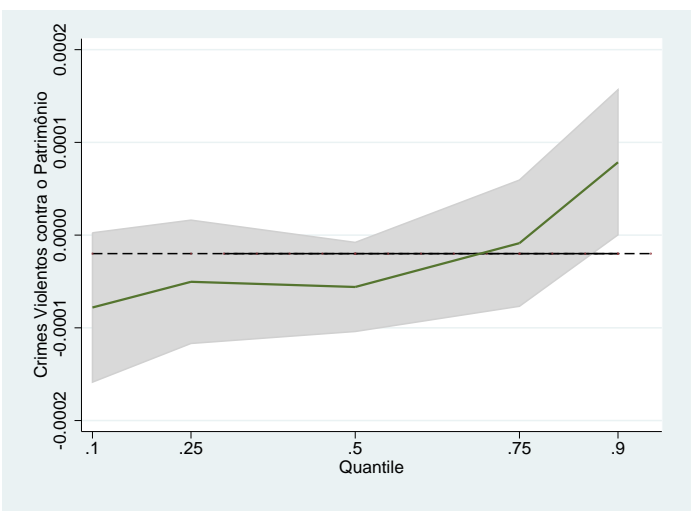

Figura 2 - Gráfico dos Coeficientes da Regressão Quantílica de Estabilidade Emocional e Crimes Violentos Contra Patrimônio - $3^{\circ}$ ano do EM

Assim, a partir da análise dos gráficos que representam os coeficientes das regressões quantílicas estimadas, não se pode concluir que há um padrão na associação entre violência e habilidades socioemocionais de forma a prejudicar alunos que se encontram nas partes inferiores das distribuições dessas características.

\subsection{Análise de Mediação}

Uma vez constatada a relação entre violência e as habilidades socioemocionais, cabe investigar se o efeito da violência sobre a proficiência se dá por meio dessas últimas. Para tanto, foram estimadas equações a partir de um Modelo de Equações Estruturais, conforme a seção metodológica. Os efeitos diretos reportados nas tabelas são os coeficientes da variável de violência para a equação na qual a proficiência é a variável dependente. Ou seja, o efeito direto capta a associação entre violência e proficiência e é representado pelo $c^{\prime}$ da equação 3. Já o efeito indireto é o coeficiente da variável de violência para a 
equação na qual a habilidade socioemocional é a variável dependente vezes o coeficiente da variável de habilidade socioemocional na equação onde a proficiência é a variável dependente. Assim, o efeito indireto capta a associação entre a violência e a proficiência através do socioemocional e é representado pelo produto $a b$, das equações 2 e 3 . O efeito total é a soma dos efeitos direto e indireto. Esses modelos foram estimados separadamente para as proficiências de língua portuguesa e matemática e para o $1^{\circ}$ e $3^{\circ}$ anos do ensino médio, conforme tabelas a seguir.

Tabela 15 - Análise de Mediação da Relação entre Violência e Proficiências de Matemática através das Habilidades Socioemocionais - $1^{\circ}$ ano do EM

\begin{tabular}{lllllll}
\hline \hline Efeito & Consciec. & Extroversão & Est. Emoc. & Loc. Contr. & Amabilidade & Abertura \\
\hline \multicolumn{7}{c}{ Crimes Violentos Letais e Intencionais } \\
\hline Direto & $-0,005085^{* * *}$ & $-0,004889^{* *}$ & $0,004904^{* *}$ & $0,004839^{* *}$ & $-0,0048941^{* *}$ & $-0,004882^{* *}$ \\
Indireto & $0,000210^{* *}$ & 0,000011 & $-0,000029$ & 0,000039 & 0,000015 & 0,000004 \\
Total & $-0,004875^{* *}$ & $-0,004878^{* *}$ & $0,004875^{* *}$ & $0,004878^{* *}$ & $-0,004880^{* *}$ & $-0,004878^{* *}$ \\
\hline \multicolumn{7}{c}{ Crimes Violentos Não Letais Contra a Pessoa } \\
\hline Direto & $-0,000163$ & $-0,000165$ & 0,000156 & 0,000161 & $-0,000143$ & $-0,000153$ \\
Indireto & 0,000004 & $0,000005^{* *}$ & 0,000003 & $-0,000001$ & $-0,000017^{* * *}$ & $-0,000007$ \\
Total & $-0,000159$ & $-0,000160$ & 0,000159 & 0,000160 & $-0,000160$ & $-0,000160$ \\
\hline \multicolumn{7}{c}{ Crimes Contra Patrimônio } \\
\hline $\begin{array}{l}\text { Direto } \\
\text { Indireto }\end{array}$ & $-0,000301^{* * *}$ & $-0,000302^{* * *}$ & $0,000298^{* * *}$ & $0,000300^{* * *}$ & $-0,000295^{* * *}$ & $-0,000296^{* * *}$ \\
Total & $-0,000002$ & $0,000002^{* *}$ & 0,000001 & 0,000000 & $-0,000005^{* * *}$ & $-0,000004^{* * *}$ \\
\hline \hline
\end{tabular}

Tanto a proficiência em matemática quanto a em língua portuguesa estão normalizadas, com média zero e variância um. Dessa maneira, assim como os coeficientes das regressões por $\mathrm{MQO}$, os efeitos diretos, indiretos e totais estão representados em desvios-padrão. Analisando os coeficientes estatisticamente significantes dos efeitos indiretos calculados para o $1^{\circ}$ ano do ensino médio, é possível concluir que ocorre mediação no mesmo sentido que o efeito causado diretamente pela violência sobre a nota através dos 
construtos de amabilidade e abertura a novas experiências. Assim, a exposição à violência estaria diminuindo o desempenho em matemática dos alunos ao afetar negativamente essas duas dimensões socioemocionais. Contudo, esse efeito indireto da violência sobre nota representa somente 1,7 e 1,3\% do efeito total da violência sobre a nota, o que é uma parcela pequena.

Tabela 16 - Análise de Mediação da Relação entre Violência e Proficiências de Língua Portuguesa através das Habilidades Socioemocionais - $1^{\circ}$ ano do EM

\begin{tabular}{lllllll}
\hline \hline Efeito & Consciec. & Extroversão & Est. Emoc. & Loc. Contr. & Amabilidade & Abertura \\
\hline \multicolumn{7}{c}{ Crimes Violentos Letais e Intencionais } \\
\hline Direto & $-0,005852^{* * *}$ & $-0,005691^{* * *}$ & $0,005708^{* * *}$ & $0,005614^{* * *}$ & $-0,005698^{* * *}$ & $-0,005693^{* * *}$ \\
Indireto & $0,000168^{* *}$ & 0,000006 & $-0,000023$ & 0,000071 & 0,000015 & 0,000009 \\
Total & $-0,005685^{* * *}$ & $-0,005685^{* * *}$ & $0,005685^{* * *}$ & $0,005685^{* * *}$ & $-0,005683^{* * *}$ & $-0,005685^{* * *}$ \\
\hline \multicolumn{7}{c}{ Crimes Violentos Não Letais Contra a Pessoa } \\
\hline Direto & $-0,000242$ & $-0,000242$ & 0,000237 & 0,000240 & $-0,000222$ & $-0,000223$ \\
Indireto & 0,000003 & 0,000003 & 0,000002 & $-0,000001$ & $-0,000017^{* * *}$ & $-0,000016$ \\
Total & $-0,000239$ & $-0,000239$ & 0,000239 & 0,000239 & $-0,000239$ & $-0,000239$ \\
\hline \multicolumn{7}{c}{ Crimes Contra Patrimônio } \\
\hline Direto & $-0,000334^{* * *}$ & $-0,000334^{* * *}$ & $0,000331^{* * *}$ & $0,000333^{* * *}$ & $-0,000328^{* * *}$ & $-0,000323^{* * *}$ \\
Indireto & 0,000001 & $0,000001^{*}$ & 0,000001 & $-0,000001$ & $-0,000005^{* * *}$ & $-0,000009^{* * *}$ \\
Total & $-0,000333^{* * *}$ & $-0,000333^{* * *}$ & $0,000333^{* * *}$ & $0,000333^{* * *}$ & $-0,000333^{* * *}$ & $-0,000333^{* * *}$ \\
\hline \hline
\end{tabular}

Nota: * Significante a $10 \%$; $*$ Significante a $5 \% ; * * *$ Significante a $1 \%$. Efeito indireto é representado pelo produto $a b$, estimado pelas equações 2 e 3 , efeito direto o $c^{\prime}$ da equação 3 e o efeito total a soma dos efeitos indireto e direto. Em todos os casos, as variáveis de controle utilizadas foram: sexo; idade; raça; nível de educação da mãe; se jovem mora com a mãe; se pais são alfabetizados; número de livros no domicílio; se família recebe Bolsa Família; se há calçadas, energia, água, saneamento e serviço doméstico onde vivem; quantos banheiros, refrigeradores, máquinas de lavar, DVDs, automóveis, dicionários há no domicílio; se há computador com internet no domicílio; hábitos de leitura dos pais e dos filhos; se pais incentivam a leitura; notas de português e matemática do SAERJINHO. Os erros-padrão corrigidos por clusters de delegacias são apresentados entre parênteses. Fonte: Elaboração própria com dados do ISP-RJ (2012-2013) e base SENNA 2013.

O resultado é semelhante para as proficiências de língua portuguesa de alunos do mesmo ano, a não ser pelo efeito indireto através de abertura a novas experiências representar uma parcela um pouco maior do efeito total, aproximando-se dos $3 \%$. 
Tabela 17 - Análise de Mediação da Relação entre Violência e Proficiências de Matemática através das Habilidades Socioemocionais - $3^{\circ}$ ano do EM

\begin{tabular}{|c|c|c|c|c|c|c|}
\hline Efeito & Consciec. & Extroversão & Est. Emoc. & Loc. Contr. & Amabilidade & Abertura \\
\hline \multicolumn{7}{|c|}{ Crimes Violentos Letais e Intencionais } \\
\hline Direto & $-0,006098$ & $-0,006067$ & 0,006075 & 0,006021 & $-0,006062$ & $-0,005994$ \\
\hline Indireto & 0,000030 & $-0,000001$ & $-0,000008$ & 0,000047 & $-0,000006$ & $-0,000074$ \\
\hline Total & $-0,006067$ & $-0,006067$ & 0,006067 & 0,006067 & $-0,006067$ & $-0,006067$ \\
\hline \multicolumn{7}{|c|}{ Crimes Violentos Não Letais Contra a Pessoa } \\
\hline Direto & 0,000290 & 0,000283 & $-0,000282$ & $-0,000287$ & 0,000280 & 0,000273 \\
\hline Indireto & $-0,000007$ & 0,000000 & $-0,000001$ & 0,000004 & 0,000003 & 0,000009 \\
\hline & 0,000283 & 0,000283 & $-0,000283$ & $-0,000283$ & 0,000283 & 0,000283 \\
\hline \multicolumn{7}{|c|}{ Crimes Contra Patrimônio } \\
\hline Direto & $-0,000389^{* * *}$ & $-0,000391^{* * *}$ & $0,000390^{* * *}$ & $0,000389^{* * *}$ & $-0,000388^{* * *}$ & $-0,000386^{* * *}$ \\
\hline Indireto & $-0,000001$ & 0,000000 & 0,000000 & 0,000001 & $-0,000002$ & $-0,000004^{* *}$ \\
\hline Total & $-0,000390^{* * *}$ & $-0,000390^{* * *}$ & $0,000390^{* * *}$ & $0,000390^{* * *}$ & $-0,000390^{* * *}$ & $-0,000390^{* * *}$ \\
\hline alfabe & $\begin{array}{l}\text { s; número de } \\
\text { tico onde vive }\end{array}$ & $\begin{array}{l}\text { tilizadas foram: se } \\
\text { vros no domicílio; } \\
\text {; quantos banheir }\end{array}$ & $\begin{array}{l}\text { o; idade; raça; } n \\
\text { e família recebe } \\
\text {, refrigeradores }\end{array}$ & $\begin{array}{l}\text { e educaçao da } \\
\text { a Família; se } \\
\text { ¡uinas de lava }\end{array}$ & $\begin{array}{l}\text { alçadas, ener } \\
\text { vs, automó }\end{array}$ & $\begin{array}{l}\text { lo produto } a b \text {, } \\
\text { t. Em todos os } \\
\text { a mãe; se pais } \\
\text { la, saneamento } \\
\text { ionários há no }\end{array}$ \\
\hline
\end{tabular}

Já para o $3^{\circ}$ ano do ensino médio, são identificados os mesmos canais de mediação para língua portuguesa, mas somente via abertura a novas experiências para matemática. O efeito indireto representa uma parcela um pouco maior do efeito total para o caso de língua portuguesa, indicando que poderia estar ocorrendo um processo de mediação levemente mais intensos através dessa proficiência. 
Tabela 18 - Análise de Mediação da Relação entre Violência e Proficiências de Língua Portuguesa através das Habilidades Socioemocionais - $3^{\circ}$ ano do EM

\begin{tabular}{lllllll}
\hline \hline Efeito & Consciec. & \multicolumn{7}{c}{ Extroversão } & Est. Emoc. & Loc. Contr. & Amabilidade & Abertura \\
\hline \multicolumn{7}{c}{ Crimes Violentos Letais e Intencionais } \\
\hline Direto & $-0,003592$ & $-0,003568$ & 0,003598 & 0,003496 & $-0,003561$ & $-0,003489$ \\
Indireto & 0,000021 & $-0,000003$ & $-0,000026$ & 0,000075 & $-0,000010$ & $-0,000082$ \\
Total & $-0,003571$ & $-0,003571$ & 0,003571 & 0,003571 & $-0,003571$ & $-0,003571$ \\
\hline \multicolumn{7}{c}{ Crimes Violentos Não Letais Contra a Pessoa } \\
\hline Direto & 0,000210 & 0,000204 & $-0,000202$ & $-0,000211$ & 0,000200 & 0,000194 \\
Indireto & $-0,000005$ & 0,000000 & $-0,000003$ & 0,000006 & 0,000005 & 0,000010 \\
Total & 0,000205 & 0,000205 & $-0,000205$ & $-0,000205$ & 0,000205 & 0,000205 \\
\hline \multicolumn{7}{c}{ Crimes Contra Patrimônio } \\
\hline Direto & $-0,000280^{* * *}$ & $-0,000281^{* * *}$ & $0,000281^{* * *}$ & $0,000279^{* * *}$ & $-0,000276^{* * *}$ & $-0,000277^{* * *}$ \\
Indireto & $-0,000001$ & 0,000000 & $-0,000000$ & 0,000002 & $-0,000005^{* * *}$ & $-0,000005^{* *}$ \\
Total & $-0,000281^{* * *}$ & $-0,000281^{* * *}$ & $0,000281^{* * *}$ & $0,000281^{* * *}$ & $-0,000281^{* * *}$ & $-0,000281^{* * *}$ \\
\hline \hline
\end{tabular}

Nota: * Significante a $10 \%$; ** Significante a $5 \%$; ** Significante a $1 \%$. Efeito indireto é representado pelo produto $a b$, estimado pelas equações 2 e 3 , efeito direto o $c^{\prime}$ da equação 3 e o efeito total a soma dos efeitos indireto e direto. Em todos os casos, as variáveis de controle utilizadas foram: sexo; idade; raça; nível de educação da mãe; se jovem mora com a mãe; se pais são alfabetizados; número de livros no domicílio; se família recebe Bolsa Família; se há calçadas, energia, água, saneamento e serviço doméstico onde vivem; quantos banheiros, refrigeradores, máquinas de lavar, DVDs, automóveis, dicionários há no domicílio; se há computador com internet no domicílio; hábitos de leitura dos pais e dos filhos; se pais incentivam a leitura; notas de português e matemática do SAERJINHO. Os erros-padrão corrigidos por clusters de delegacias são apresentados entre parênteses. Fonte: Elaboração própria com dados do ISP-RJ (2012-2013) e base SENNA 2013.

Uma vez que a associação encontrada entre as habilidades socioemocionais dos estudantes e sua exposição à violência na comunidade foi baixa, espera-se que a violência não afete a proficiência de forma muito substantiva através desse canal, que foi o que esse último exercício demonstrou. Outra possível explicação para a baixa parcela mediada da relação entre violência e notas através das habilidades socioemocionais é que a violência pode ter efeito mais acentuado sobre algumas características não cognitivas, mas elas não estarem muito fortemente associadas ao desempenho escolar. O contrário também pode ser verdade na medida em que a violência não afeta aquelas dimensões socioemocionais que estão mais associadas às proficiências. 


\section{Considerações Finais}

De acordo com a literatura, há uma relação negativa entre a violência e o desempenho dos alunos, levando a crer que a criminalidade no entorno da escola prejudica o desempenho acadêmico. Esse impacto pode se dar por diversas vias, sendo uma delas a psicológica. Assim, o presente estudo procurou analisar a associação entre a violência e as habilidades socioemocionais dos alunos e investigar se essas funcionam como um mediador para o efeito da violência sobre as notas, uma vez que já se sabe que as características não cognitivas dos estudantes influenciam seu aprendizado.

A partir dos resultados obtidos, é possível concluir que a dimensão socioemocional mais fortemente associada à exposição à violência para os estudantes do ensino médio da rede pública do estado do Rio de Janeiro é a amabilidade. Essa habilidade compreende as facetas de confiança no próximo (tolerância), objetividade, altruísmo, obediência, modéstia e docilidade (simpatia), que podem estar sendo afetadas pela violência. Extroversão e abertura a novas experiências também demonstraram relações negativas robustas com a exposição à violência. Contudo, cabe ressaltar que a magnitude de todas essas relações na prática é baixa. Assim, frente à ameaça da violência à qual os jovens encontram-se expostos, eles desenvolvem mudanças comportamentais ou até psicológicas como mecanismos de defesa ou de lidar com o estresse, o que se reflete em seus traços de personalidade.

Em relação às análises de heterogeneidade, não há padrões muito diferentes para a relação entre violência e habilidades socioemocionais de meninos e meninas nem para alunos de altas e baixas proficiências. Já para alunos com mães de diferentes níveis de escolaridade, existe um padrão distinto, de forma que a escolaridade da mãe parece agir como um fator protetivo que diminui a associação (principalmente negativa) entre violência e as características não cognitivas dos estudantes.

Das três categorias de crimes estudadas, a que apresentou mais relação com as habilidades socioemocionais foi a de crimes contra patrimônio, provavelmente por esse conter o maior número de ocorrências e menores erros de medida, uma vez que fazem parte desse índice os roubos a bancos, caixas eletrônicos e veículos, que costumam ser 
registrados com maior acuracidade.

Sobre as regressões quantílicas, de uma forma geral, não foi possível encontrar um padrão muito claro de como ocorre a associação entre violência e as características socioemocionais para alunos em diferentes pontos das distribuições dessas habilidades. Contudo, para o $1^{\circ}$ ano do ensino médio, a relação entre abertura a novas experiências e crimes violentos não letais é maior para os alunos da parte inferior da distribuição dessa habilidade socioemocional, do que para os demais alunos e esse padrão se repete em algumas outras poucas relações estudadas.

Em relação à análise de mediação do efeito da violência sobre as proficiências através das habilidades socioemocionais, foi possível concluir que essa mediação existe, porém, sua importância é relativamente pequena. A maior parte do efeito é direto. Pode ser que construtos que estão mais associados com a nota são menos afetados pela violência e que construtos mais afetados pela violência impactam menos a nota. De qualquer forma, foi possível concluir que essa mediação acontece por meio dos construtos da amabilidade e da abertura a novas experiências. Apesar de extroversão ter sido o segundo construto mais associado aos índices de violência nas análises por Mínimos Quadrados Ordinários, os efeitos indiretos da criminalidade sobre as notas através dele estimados pelo Modelo de Equações Estruturais não se mostraram estatisticamente significantes. Isso pode ter ocorrido em razão de extroversão ser a habilidade socioemocional que está menos relacionada a resultados educacionais (SANTOS; PRIMI, 2014). Embora a mediação tenha sido constatada para as duas habilidades já citadas, a parcela do impacto da violência sobre as notas mediada por essas habilidades é bastante baixa.

O presente estudo procurou demonstrar a associação entre violência, habilidades socioemocionais e proficiência escolar. Apesar de não ter sido possível inferir causalidade, ele tem sua importância pelo pioneirismo da relação estudada. Assim, futuros trabalhos podem analisar essa associação de uma forma que permita o estabelecimento de uma relação causal, o que depende da disponibilidade de novas bases de dados para a composição de um painel, por exemplo. 


\section{Referências}

ALBERNAZ, Â.; FERREIRA, F. H.; FRANCO, C. Qualidade e eqüidade na educação fundamental brasileiro. Pesquisa e Planejamento Econômico, v. 33, n. 3, 2002.

ALLPORT, G. W. Personality: A psychological interpretation. Holt, 1937.

ALMLUnD, M. et al. Personality psychology and economics. [S.1.], 2011.

BORGHANS, L. et al. The economics and psychology of personality traits. Journal of human Resources, University of Wisconsin Press, v. 43, n. 4, p. 972-1059, 2008.

BUCKNER, J. C.; BEARDSLEE, W. R.; BASSUK, E. L. Exposure to violence and lowincome children's mental health: direct, moderated, and mediated relations. American Journal of Orthopsychiatry, Educational Publishing Foundation, v. 74, n. 4, p. 413, 2004.

CARNEIRO, P.; CRAWFORD, C.; GOODMAN, A. The impact of early cognitive and non-cognitive skills on later outcomes. Centre for Economics of Education, 2007.

CIA, F.; BARHAM, E. J. Repertório de habilidades sociais, problemas de comportamento, autoconceito e desempenho acadêmico de crianças no início da escolarização; social skills repertory, behavioral problems, self-concept and academic performance among children in their early school years. Estud. psicol.(Campinas), v. 26, n. 1, p. 45-55, 2009.

COLEMAN, J. S. et al. Equality of educational opportunity. Washington, dc, p. 10665684, 1966.

COOLEY-QUILLE, M. et al. Emotional and behavioral impact of exposure to community violence in inner-city adolescents. Journal of clinical child psychology, Taylor \& Francis, v. 30, n. 2, p. 199-206, 2001.

COOLEY-QUILlE, M. R.; TURNER, S. M.; BEIDEL, D. C. Emotional impact of children's exposure to community violence: A preliminary study. Journal of the American Academy of Child \& Adolescent Psychiatry, Elsevier, v. 34, n. 10, p. 1362-1368, 1995.

DELORS, J. et al. Relatório para a unesco da comissão internacional sobre educação para o século xxi. Educação: um tesouro a descobrir. São Paulo: UNESCO, 1999.

DIA, O. Medo da violencia afeta cerebro de criancas e jovens e provoca doencas. 2015. Disponível em: <http://saude.ig.com.br/minhasaude/2015-09-13/ medo-da-violencia-afeta-cerebro-de-criancas-e-jovens-e-provoca-doencas.html > .

DUNCAN, G. J.; MAGNUSON, K. The nature and impact of early achievement skills, attention skills, and behavior problems. Whither opportunity, p. 47-69, 2011.

FOWLER, P. J. et al. Community violence: A meta-analysis on the effect of exposure and mental health outcomes of children and adolescents. Development and psychopathology, Cambridge Univ Press, v. 21, n. 01, p. 227-259, 2009.

GAMA, V. A.; SCORZAFAVE, L. G. Os efeitos da criminalidade sobre a proficiência escolar no ensino fundamental no município de são paulo. Pesquisa e Planejamento Econômico, v. 43, n. 3, 2013. 
GONÇALVES, M.; RAPOSO, I.; GOMES, S. A relação entre habilidades não-cognitivas e desempenho escolar. 2014.

GUERRA, N. G.; HUESMANN, L. R.; SPINDLER, A. Community violence exposure, social cognition, and aggression among urban elementary school children. Child development, JSTOR, p. 1561-1576, 2003.

HARDAWAY, C. R.; MCLOYD, V. C.; WOOD, D. Exposure to violence and socioemotional adjustment in low-income youth: An examination of protective factors. American journal of community psychology, Springer, v. 49, n. 1-2, p. 112-126, 2012.

HECKMAN, J. J. The economics of inequality: The value of early childhood education. American Educator, ERIC, v. 35, n. 1, p. 31, 2011.

HECKMAN, J. J.; KAUTZ, T. Hard evidence on soft skills. Labour economics, Elsevier, v. 19, n. 4, p. 451-464, 2012.

HECKMAN, J. J.; PINTO, R.; SAVELYEV, P. A. Understanding the mechanisms through which an influential early childhood program boosted adult outcomes. [S.l.], 2012.

HESS, A. R. B.; FALCKE, D. Sintomas internalizantes na adolescência e as relações familiares: uma revisão sistemática da literatura. Psico USF, v. 18, n. 2, p. 263-276, 2013.

JOHN, O. P.; SRIVASTAVA, S. The big five trait taxonomy: History, measurement, and theoretical perspectives. Handbook of personality: Theory and research, Guilford, v. 2, n. 1999 , p. $102-138,1999$.

KOENKER, R.; JR, G. B. Regression quantiles. Econometrica: journal of the Econometric Society, JSTOR, p. 33-50, 1978.

LEE, V. E.; BURKAM, D. T. Inequality at the starting gate: Social background differences in achievement as children begin school. [S.l.]: ERIC, 2002.

LEE, W. O. Education and 21st century competencies. Keynote paper presented at the Education and 21st Century Competencies,hosted by the Ministry of Education, Oman, 2013.

LLERAS, C. Do skills and behaviors in high school matter? the contribution of noncognitive factors in explaining differences in educational attainment and earnings. Social Science Research, Elsevier, v. 37, n. 3, p. 888-902, 2008.

LOUNSBURY, J. W. et al. An investigation of personality traits in relation to adolescent school absenteeism. Journal of Youth and Adolescence, Springer, v. 33, n. 5, p. 457-466, 2004.

MARGOLIN, G. et al. Violence exposure in multiple interpersonal domains: Cumulative and differential effects. Journal of Adolescent Health, Elsevier, v. 47, n. 2, p. 198-205, 2010 .

MCDONALD, C. C.; RICHMOND, T. R. The relationship between community violence exposure and mental health symptoms in urban adolescents. Journal of psychiatric and mental health nursing, Wiley Online Library, v. 15, n. 10, p. 833-849, 2008. 
NG-MAK, D. S. et al. Pathologic adaptation to community violence among inner-city youth. American Journal of Orthopsychiatry, Educational Publishing Foundation, v. 74, n. 2, p. 196, 2004.

OVERSTREET, S.; BRAUN, S. Exposure to community violence and post-traumatic stress symptoms: Mediating factors. American Journal of Orthopsychiatry, American Orthopsychiatric Association, Inc., v. 70, n. 2, p. 263, 2000.

OVERSTREET, S.; MAZZA, J. An ecological-transactional understanding of community violence: Theoretical perspectives. School Psychology Quarterly, Guilford Publications, v. 18, n. 1, p. 66, 2003.

PERKINS, S.; GRAHAM-BERMANN, S. Violence exposure and the development of school-related functioning: Mental health, neurocognition, and learning. Aggression and violent behavior, Elsevier, v. 17, n. 1, p. 89-98, 2012.

POROPAT, A. E. A meta-analysis of the five-factor model of personality and academic performance. Psychological bulletin, American Psychological Association, v. 135, n. 2, p. 322, 2009.

PORTO, J. A. D. Conceito e diagnóstico. Revista Brasileira de Psiquiatria, SciELO Brasil, v. 21, p. 06-11, 1999.

POTTER, L. B. Understanding the incidence and origins of community violence: Toward a comprehensive perspective of violence prevention. Sage Publications, Inc, 1999.

ROMER, D. D. Advanced macroeconomics. Published byMcGraw-Hill/Irwin, 2006.

SANTOS, D.; PRIMI, R. Desenvolvimento socioemocional e aprendizado escolar: Uma proposta de mensuração para apoiar polícas públicas. 2014 .

SCHWAB-STONE, M. E. et al. No safe haven: A study of violence exposure in an urban community. Journal of the American Academy of Child $\& 5$ Adolescent Psychiatry, Elsevier, v. 34, n. 10, p. 1343-1352, 1995.

SEVERNINI, E. R. A relação entre violência nas escolas e proficiência dos alunos. Catholic University of Rio de Janeiro, Rio de Janeiro, Brazil. Unpublished manuscript, 2007.

SOUZA, B. D. B. de; PRIMI, R. Revisão da dimensão conscienciosidade do inventário dimensional clínico da personalidade (revision of the conscientiousness dimension of the dimensional clinical personality inventory). Revista CES Psicología, v. 7, n. 2, p. 1-14, 2014.

TEIXEIRA, E. C.; KASSOUF, A. L. Impacto da violência nas escolas paulistas sobre o desempenho acadêmico dos alunos. Economia Aplicada, SciELO Brasil, v. 19, n. 2, p. 221-240, 2015. 


\section{Apêndice}

Tabela 19 - Relação entre Habilidades Socioemocionais e Crimes Letais Intencionais - $1^{\circ}$ ano do EM

\begin{tabular}{|c|c|c|c|c|c|c|}
\hline & Consciec. & Extroversão & Est. Emoc. & Loc. Contr. & Amabilidade & Abertura \\
\hline$R^{2}$ & 0,13678 & 0,040524 & 0,113768 & 0,056515 & 0,07273 & 0,139704 \\
\hline $\mathrm{N}$ & 12.693 & 12.694 & 12.693 & 12.694 & 12.693 & 12.694 \\
\hline Letais Intencionais & $0,002177^{* *}$ & $-0,000443$ & $-0,000787$ & 0,00051 & 0,000356 & 0,000154 \\
\hline 12 anos ou menos & $-0,13977$ & $-0,186967$ & $-0,119601$ & 0,216972 & $-0,042802$ & $-0,237782$ \\
\hline 13 anos & $-0,226208^{*}$ & $0,189124^{*}$ & 0,029512 & 0,018678 & $-0,028324$ & 0,084252 \\
\hline 14 anos & $-0,266876^{* *}$ & $0,195196^{* *}$ & 0,083968 & $-0,036201$ & $-0,042491$ & 0,07322 \\
\hline 15 anos & $-0,231127^{* *}$ & $0,197629^{* * *}$ & 0,073399 & $-0,019139$ & $-0,053849$ & 0,064399 \\
\hline 16 anos & $-0,325382^{* * *}$ & $0,191338^{* * *}$ & 0,104922 & 0,004829 & $-0,098745$ & 0,035156 \\
\hline 17 anos & $-0,291561^{* * *}$ & 0,093701 & 0,067716 & $-0,037614$ & $-0,10697$ & $-0,016688$ \\
\hline Pardo & 0,00281 & $0,097498^{* * *}$ & 0,012408 & $0,046204^{* *}$ & $-0,010062$ & $-0,000225$ \\
\hline Negro & $-0,095914^{* * *}$ & $0,166111^{* * *}$ & 0,007277 & $0,098996^{* * *}$ & $-0,043552$ & $-0,041264^{* *}$ \\
\hline Amarelo & $-0,158160^{* * *}$ & $-0,00673$ & $0,096799 * * *$ & $0,102763^{* * *}$ & $-0,155247^{* * *}$ & $-0,046338$ \\
\hline Indígena & $-0,095641^{*}$ & $0,121716^{* *}$ & 0,017429 & $0,149155^{* *}$ & $-0,030585$ & $0,084304^{*}$ \\
\hline Masculino & $-0,089790^{* * *}$ & $-0,198734^{* * *}$ & $-0,644718^{* * *}$ & $0,046635^{* *}$ & $-0,151426^{* * *}$ & $0,054376^{* * *}$ \\
\hline Mora com a mãe & 0,035083 & $-0,132878^{* * *}$ & $-0,096220^{* *}$ & $-0,176648^{* * *}$ & $-0,082792^{* *}$ & $-0,127858^{* * *}$ \\
\hline Não mora com a mãe & 0,005541 & $-0,086351$ & $-0,009595$ & $-0,08691$ & $-0,154148^{* * *}$ & $-0,082924$ \\
\hline Mãe completou $5^{\circ}$ ano & $0,061382^{*}$ & 0,043343 & 0,008018 & $-0,0272$ & $0,065168^{*}$ & $0,089846^{* *}$ \\
\hline Mãe completou $9^{\circ}$ ano & 0,024078 & 0,075562 & $-0,009551$ & $-0,040856$ & 0,048341 & $0,109241^{* * *}$ \\
\hline Mãe completou EM & 0,000986 & 0,078121 & 0,04747 & $-0,042843$ & 0,006675 & $0,086428^{* *}$ \\
\hline Mãe completou ES & $-0,020745$ & 0,062201 & 0,051806 & $-0,015712$ & 0,070413 & $0,141798^{* * *}$ \\
\hline Escolaridade da mãe ND & $-0,05894$ & $-0,089908^{* *}$ & 0,047018 & 0,035039 & $-0,057106$ & $-0,089934^{* *}$ \\
\hline Rua pavimentada & $-0,034985$ & $0,036905^{*}$ & $0,047746^{* *}$ & $-0,007973$ & $-0,03232$ & $-0,003318$ \\
\hline Energia Elétrica & $0,227957^{*}$ & $0,402614^{* * *}$ & $-0,156414$ & $-0,515298^{* * *}$ & $0,604241^{* * *}$ & 0,047504 \\
\hline Água encanada & 0,055945 & $-0,122147^{*}$ & $-0,063134$ & $-0,127149^{*}$ & $0,111122^{*}$ & $-0,028062$ \\
\hline Coleta de lixo & $-0,110802^{* * *}$ & 0,023417 & $-0,033644$ & $-0,079631^{* *}$ & $-0,055369^{*}$ & $-0,012408$ \\
\hline Bolsa Família & $0,047667^{* * *}$ & $-0,013036$ & 0,022722 & $0,042618^{* *}$ & $-0,00652$ & $-0,020473$ \\
\hline Empregada doméstica & $-0,122118^{* * *}$ & $0,073720^{* *}$ & $0,097883^{* *}$ & 0,040973 & $-0,155256^{* * *}$ & $-0,029799$ \\
\hline Possui Automóvel & $-0,024457$ & $0,070411^{* * *}$ & $0,088364^{* * *}$ & $-0,002879$ & $-0,010203$ & 0,013869 \\
\hline Possui lavadora de roupas & $-0,173209 * * *$ & $-0,018793$ & $0,076429^{* * *}$ & $0,067559^{* * *}$ & $-0,106159^{* * *}$ & $-0,097162^{* * *}$ \\
\hline Possui de 1 a 20 livros & $0,094405^{* * *}$ & $0,091066^{* * *}$ & $-0,033358$ & $-0,101931^{* * *}$ & $0,126405^{* * *}$ & $0,205415^{* * *}$ \\
\hline Possui de 21 a 100 livros & $0,127469^{* * *}$ & $0,160263^{* * *}$ & $-0,027226$ & $-0,087128^{* *}$ & $0,186721^{* * *}$ & $0,422604 * * *$ \\
\hline Possui mais de 100 livros & $0,127090^{* *}$ & $0,175708^{* * *}$ & 0,040639 & 0,018926 & $0,103363^{* *}$ & $0,427105^{* * *}$ \\
\hline Pais lêem raramente & $-0,141262^{* * *}$ & 0,065251 & $-0,028488$ & $-0,027199$ & 0,017163 & 0,028292 \\
\hline Pais lêem ocasionalmente & $-0,028217$ & $0,108796^{* *}$ & $-0,126256^{* * *}$ & $-0,146657^{* * *}$ & 0,016851 & 0,034061 \\
\hline Pais lêem frequentemente & 0,038953 & $0,240507^{* * *}$ & $-0,159870^{* * *}$ & $-0,235980^{* * *}$ & $0,118649^{* *}$ & $0,117250^{* * *}$ \\
\hline Pais incentivam a leitura & $0,255481^{* * *}$ & $0,096374 * * *$ & $-0,098722^{* * *}$ & $-0,210587^{* * *}$ & $0,206063^{* * *}$ & $0,129935^{* * *}$ \\
\hline Criança lê raramente & $0,346741^{* * *}$ & $-0,017126$ & $-0,093911^{* *}$ & $-0,089770^{* * *}$ & $0,162536^{* * *}$ & $0,190281 * * *$ \\
\hline Criança lê ocasionalmente & $0,710122^{* * *}$ & 0,01925 & $-0,250840^{* * *}$ & $-0,243307^{* * *}$ & $0,360724^{* * *}$ & $0,449424 * * *$ \\
\hline Criança lê frequentemente & $1,011406^{* * *}$ & 0,053534 & $-0,334983^{* * *}$ & $-0,349617^{* * *}$ & $0,553898^{* * *}$ & $0,847213^{* * *}$ \\
\hline Escola na Área urbana & $-0,004697$ & $0,116619^{* * *}$ & $0,169347^{*}$ & $0,126662^{* *}$ & $-0,056358$ & 0,071855 \\
\hline
\end{tabular}

Nota: * Significante a $10 \%$; ** Significante a $5 \%$; ** Significante a $1 \%$. Cada linha dessa tabela representa o coeficiente da variável explicativa da regressão entre uma das variáveis de habilidade socioemocional e o indicador de crimes letais intencionais. Fonte: Elaboração própria com dados do ISP-RJ (2012-2013) e base SENNA 2013. 
Tabela 20 - Relação entre Habilidades Socioemocionais e Crimes Não Letais - $1^{\circ}$ ano do EM

\begin{tabular}{|c|c|c|c|c|c|c|}
\hline & Consciec. & Extroversão & Est. Emoc. & Loc. Contr. & Amabilidade & Abertura \\
\hline$R^{2}$ & 0,135510 & 0,040950 & 0,113622 & 0,056439 & 0,073861 & 0,139946 \\
\hline $\mathrm{N}$ & 12.693 & 12.694 & 12.693 & 12.694 & 12.693 & 12.694 \\
\hline Não Letais & 0,000045 & $-0,000157^{* *}$ & 0,000031 & 0,000011 & $-0,000245^{* * *}$ & $-0,000108$ \\
\hline 12 anos ou menos & $-0,131674$ & $-0,181244$ & $-0,124899$ & 0,218835 & $-0,028853$ & $-0,231662$ \\
\hline 13 anos & $-0,217582^{*}$ & $0,187487^{*}$ & 0,026356 & 0,020697 & $-0,026693$ & 0,084950 \\
\hline 14 anos & $-0,269307^{* *}$ & $0,196635^{* *}$ & 0,084542 & $-0,036774$ & $-0,041254$ & 0,073759 \\
\hline 15 anos & $-0,233742^{* *}$ & $0,199356^{* * *}$ & 0,073960 & $-0,019756$ & $-0,052215$ & 0,065114 \\
\hline 16 anos & $-0,327107^{* * *}$ & $0,193621^{* * *}$ & 0,104924 & 0,004417 & $-0,095704$ & 0,036488 \\
\hline 17 anos & $-0,292323^{* * *}$ & 0,094308 & 0,067841 & $-0,037796$ & $-0,106305$ & $-0,016403$ \\
\hline Pardo & 0,006629 & $0,097404^{* * *}$ & 0,010808 & $0,047095^{* *}$ & $-0,008269$ & 0,000559 \\
\hline Negro & $-0,091902^{* * *}$ & $0,165901^{* * *}$ & 0,005630 & $0,099933^{* * *}$ & $-0,041859$ & $-0,040525^{* *}$ \\
\hline Amarelo & $-0,154351^{* * *}$ & $-0,006339$ & $0,095048^{* *}$ & $0,103649^{* * *}$ & $-0,152628^{* * *}$ & $-0,045190$ \\
\hline Indígena & $-0,086318$ & $0,120234^{* *}$ & 0,013927 & $0,151336^{* * *}$ & $-0,028350$ & $0,085275^{*}$ \\
\hline Masculino & $-0,090457^{* * *}$ & $-0,198495^{* * *}$ & $-0,644510^{* * *}$ & $0,046479^{* *}$ & $-0,151356^{* * *}$ & $0,054407^{* * *}$ \\
\hline Mora com a mãe & 0,033374 & $-0,132312^{* * *}$ & $-0,095673^{* *}$ & $-0,177049^{* * *}$ & $-0,082699 * *$ & $-0,127815^{* * *}$ \\
\hline Não mora com a mãe & 0,005820 & $-0,084043$ & $-0,010457$ & $-0,086855$ & $-0,150055^{* * *}$ & $-0,081123$ \\
\hline Mãe completou $5^{\circ}$ ano & $0,058060^{*}$ & 0,044197 & 0,009160 & $-0,027979$ & $0,064927^{*}$ & $0,089745^{* *}$ \\
\hline Mãe completou $9^{\circ}$ ano & 0,022346 & 0,076652 & $-0,009163$ & $-0,041265$ & 0,049319 & $0,109674^{* * *}$ \\
\hline Mãe completou EM & $-0,001018$ & 0,079107 & 0,048008 & $-0,043315$ & 0,007334 & $0,086721^{* *}$ \\
\hline Mãe completou ES & $-0,026205$ & 0,064969 & 0,053246 & $-0,016997$ & $0,072352^{*}$ & $0,142660^{* * *}$ \\
\hline Escolaridade da mãe ND & $-0,059146$ & $-0,087807^{* *}$ & 0,046430 & 0,034982 & $-0,053621$ & $-0,088399 * *$ \\
\hline Rua pavimentada & $-0,038501$ & $0,037744^{*}$ & $0,048976^{* * *}$ & $-0,008797$ & $-0,032683$ & $-0,003473$ \\
\hline Energia Elétrica & $0,236667^{*}$ & $0,401431^{* * *}$ & $-0,159751$ & $-0,513261^{* * *}$ & $0,606672^{* * *}$ & 0,048562 \\
\hline Água encanada & 0,046641 & $-0,121695^{*}$ & $-0,059308$ & $-0,129321 *$ & $0,107134^{*}$ & $-0,029804$ \\
\hline Coleta de lixo & $-0,114554^{* * *}$ & 0,025533 & $-0,032723$ & $-0,080515^{* *}$ & $-0,053669^{*}$ & $-0,011654$ \\
\hline Bolsa Família & $0,052048^{* * *}$ & $-0,012334$ & 0,020626 & $0,043637^{* *}$ & $-0,003080$ & $-0,018965$ \\
\hline Empregada doméstica & $-0,123981 * * *$ & $0,073685^{* *}$ & $0,098689^{* *}$ & 0,040539 & $-0,156269 * * *$ & $-0,030242$ \\
\hline Possui Automóvel & $-0,025123$ & $0,069475^{* * *}$ & $0,088949^{* * *}$ & $-0,003030$ & $-0,012143$ & 0,013016 \\
\hline Possui lavadora de roupas & $-0,177173^{* * *}$ & $-0,017511$ & $0,077708^{* * *}$ & $0,066629 * * *$ & $-0,105996^{* * *}$ & $-0,097085^{* * *}$ \\
\hline Possui de 1 a 20 livros & $0,094584^{* * *}$ & $0,091597^{* * *}$ & $-0,033603$ & $-0,101891^{* * *}$ & $0,127410^{* * *}$ & $0,205856^{* * *}$ \\
\hline Possui de 21 a 100 livros & $0,125868^{* * *}$ & $0,161194^{* * *}$ & $-0,026840$ & $-0,087505^{* *}$ & $0,187499^{* * *}$ & $0,422947^{* * *}$ \\
\hline Possui mais de 100 livros & $0,129707^{* * *}$ & $0,175360^{* * *}$ & 0,039636 & 0,019539 & $0,104111^{* *}$ & $0,427429^{* * *}$ \\
\hline Pais lêem raramente & $-0,138865^{* * *}$ & 0,066143 & $-0,029799$ & $-0,026644$ & 0,019915 & 0,029500 \\
\hline Pais lêem ocasionalmente & $-0,026169$ & $0,109864^{* *}$ & $-0,127474^{* * *}$ & $-0,146184^{* * *}$ & 0,019723 & 0,035323 \\
\hline Pais lêem frequentemente & 0,043231 & $0,242033^{* * *}$ & $-0,162189^{* * *}$ & $-0,234989^{* * *}$ & $0,123447^{* * *}$ & $0,119357^{* * *}$ \\
\hline Pais incentivam a leitura & $0,254801^{* * *}$ & $0,096813^{* * *}$ & $-0,098573^{* * *}$ & $-0,210748^{* * *}$ & $0,206468^{* * *}$ & $0,130113^{* * *}$ \\
\hline Criança lê raramente & $0,349393^{* * *}$ & $-0,016864$ & $-0,095127^{* *}$ & $-0,089153^{* * *}$ & $0,164340^{* * *}$ & $0,191072^{* * *}$ \\
\hline Criança lê ocasionalmente & $0,713595^{* * *}$ & 0,018999 & $-0,252242^{* * *}$ & $-0,242496 * * *$ & $0,362069^{* * *}$ & $0,450012^{* * *}$ \\
\hline Criança lê frequentemente & $1,013506^{* * *}$ & 0,052699 & $-0,335611^{* * *}$ & $-0,349124^{* * *}$ & $0,553543^{* * *}$ & $0,847055^{* * *}$ \\
\hline Escola na Área urbana & 0,004260 & $0,104514^{* * *}$ & $0,169419 *$ & $0,128803^{* *}$ & $-0,072482^{*}$ & 0,064746 \\
\hline
\end{tabular}

Nota: * Significante a $10 \%$; ** Significante a $5 \%$; ** Significante a $1 \%$. Cada linha dessa tabela representa o coeficiente da variável explicativa da regressão entre uma das variáveis de habilidade socioemocional e o indicador de crimes não letais. Fonte: Elaboração própria com dados do ISP-RJ (2012-2013) e base SENNA 2013. 
Tabela 21 - Relação entre Habilidades Socioemocionais e Crimes Contra Patrimônio - $1^{\circ}$ ano do EM

\begin{tabular}{|c|c|c|c|c|c|c|}
\hline & Consciec. & Extroversão & Est. Emoc. & Loc. Contr. & Amabilidade & Abertura \\
\hline$R^{2}$ & 0,135514 & 0,041187 & 0,113839 & 0,056447 & 0,075328 & 0,140837 \\
\hline $\mathrm{N}$ & 12,693 & 12.694 & 12.693 & 12.694 & 12.693 & 12.694 \\
\hline Contra Patrimônio & 0,000013 & $-0,000052^{* * *}$ & 0,000031 & $-0,000006$ & $-0,000100^{* * *}$ & $-0,000063^{* * *}$ \\
\hline 12 anos ou menos & $-0,13557$ & $-0,164142$ & $-0,137954$ & 0,222328 & 0,006793 & $-0,207016$ \\
\hline 13 anos & $-0,220813^{*}$ & $0,200584^{*}$ & 0,018635 & 0,02226 & $-0,001504$ & 0,10079 \\
\hline 14 anos & $-0,269769^{* *}$ & $0,198675^{* *}$ & 0,082957 & $-0,036344$ & $-0,036991$ & 0,076734 \\
\hline 15 anos & $-0,234143^{* *}$ & $0,201193^{* * *}$ & 0,07239 & $-0,0193$ & $-0,048245$ & 0,067983 \\
\hline 16 anos & $-0,327802^{* * *}$ & $0,196783^{* * *}$ & 0,102276 & 0,005177 & $-0,088909$ & 0,041357 \\
\hline 17 anos & $-0,292775^{* * *}$ & 0,096186 & 0,066527 & $-0,037485$ & $-0,102541$ & $-0,013893$ \\
\hline Pardo & 0,005952 & $0,100270^{* * *}$ & 0,008849 & $0,047569^{* *}$ & $-0,002503$ & 0,004386 \\
\hline Negro & $-0,092883^{* * *}$ & $0,169979^{* * *}$ & 0,002988 & $0,100534^{* * *}$ & $-0,033794$ & $-0,035279^{*}$ \\
\hline Amarelo & $-0,155431^{* * *}$ & $-0,001753$ & $0,091883^{* *}$ & $0,104423^{* * *}$ & $-0,143374^{* * *}$ & $-0,039026$ \\
\hline Indígena & $-0,087278$ & $0,124197^{* *}$ & 0,011435 & $0,151885^{* * *}$ & $-0,020579$ & $0,090277^{*}$ \\
\hline Masculino & $-0,090841^{* * *}$ & $-0,196914^{* * *}$ & $-0,645475^{* * *}$ & $0,046686^{* *}$ & $-0,148280^{* * *}$ & $0,056368^{* * *}$ \\
\hline Mora com a mãe & 0,033294 & $-0,131952^{* * *}$ & $-0,095974^{* *}$ & $-0,176963^{* * *}$ & $-0,081925^{* *}$ & $-0,127262^{* * *}$ \\
\hline Não mora com a mãe & 0,006051 & $-0,084546$ & $-0,011135$ & $-0,086438$ & $-0,150123^{* * *}$ & $-0,080432$ \\
\hline Mãe completou $5^{\circ}$ ano & $0,057967^{*}$ & 0,044597 & 0,008847 & $-0,027896$ & $0,065764^{*}$ & $0,090325^{* *}$ \\
\hline Mãe completou $9^{\circ}$ ano & 0,021985 & $0,078247^{*}$ & $-0,010402$ & $-0,040929$ & 0,052665 & $0,112001^{* * *}$ \\
\hline Mãe completou EM & $-0,001617$ & $0,081633^{*}$ & 0,046289 & $-0,042902$ & 0,012408 & $0,090082^{* *}$ \\
\hline Mãe completou ES & $-0,025504$ & 0,06243 & 0,054049 & $-0,016963$ & 0,068108 & $0,140511^{* * *}$ \\
\hline Escolaridade da mãe ND & $-0,059482$ & $-0,086073^{*}$ & 0,044567 & 0,0356 & $-0,049503$ & $-0,085180^{*}$ \\
\hline Rua pavimentada & $-0,039478$ & $0,041719^{* *}$ & $0,046595^{* *}$ & $-0,008305$ & $-0,025$ & 0,001383 \\
\hline Energia Elétrica & $0,236665^{*}$ & $0,401544^{* * *}$ & $-0,160059$ & $-0,513129 * * *$ & $0,607115^{* * *}$ & 0,049022 \\
\hline Água encanada & 0,049415 & $-0,133189^{* *}$ & $-0,051985$ & $-0,130962^{*}$ & 0,084507 & $-0,044439$ \\
\hline Coleta de lixo & $-0,113310^{* * *}$ & 0,020739 & $-0,030474$ & $-0,080806^{* *}$ & $-0,062363^{*}$ & $-0,016687$ \\
\hline Bolsa Família & $0,052078^{* * *}$ & $-0,012171$ & 0,019871 & $0,043977^{* *}$ & $-0,002159$ & $-0,017894$ \\
\hline Empregada doméstica & $-0,123649^{* * *}$ & $0,072268^{* *}$ & $0,099691^{* *}$ & 0,040289 & $-0,159148^{* * *}$ & $-0,032176$ \\
\hline Possui Automóvel & $-0,023732$ & $0,063652^{* * *}$ & $0,092802^{* * *}$ & $-0,00393$ & $-0,023738$ & 0,005413 \\
\hline Possui lavadora de roupas & $-0,178074^{* * *}$ & $-0,013782$ & $0,075324^{* * *}$ & $0,067163^{* * *}$ & $-0,098650^{* * *}$ & $-0,092332^{* * *}$ \\
\hline Possui de 1 a 20 livros & $0,094600^{* * *}$ & $0,091649^{* * *}$ & $-0,033856$ & $-0,101771^{* * *}$ & $0,127724^{* * *}$ & $0,206230^{* * *}$ \\
\hline Possui de 21 a 100 livros & $0,125590^{* * *}$ & $0,162442^{* * *}$ & $-0,027808$ & $-0,087237^{* *}$ & $0,190125^{* * *}$ & $0,424783^{* * *}$ \\
\hline Possui mais de 100 livros & $0,129173^{* *}$ & $0,177573^{* * *}$ & 0,038276 & 0,019837 & $0,108429^{* *}$ & $0,430196^{* * *}$ \\
\hline Pais lêem raramente & $-0,138789^{* * *}$ & 0,066086 & $-0,030335$ & $-0,026373$ & 0,020332 & 0,030189 \\
\hline Pais lêem ocasionalmente & $-0,026593$ & $0,111846^{* *}$ & $-0,129247^{* * *}$ & $-0,145653^{* * *}$ & 0,024097 & 0,038525 \\
\hline Pais lêem frequentemente & 0,042371 & $0,245945^{* * *}$ & $-0,165472^{* * *}$ & $-0,234047^{* * *}$ & $0,131875^{* * *}$ & $0,125384^{* * *}$ \\
\hline Pais incentivam a leitura & $0,254896^{* * *}$ & $0,096479^{* * *}$ & $-0,098502^{* * *}$ & $-0,210727^{* * *}$ & $0,205938^{* * *}$ & $0,129876^{* * *}$ \\
\hline Criança lê raramente & $0,349538^{* * *}$ & $-0,017308$ & $-0,095199^{* *}$ & $-0,089043^{* * *}$ & $0,163793^{* * *}$ & $0,190977^{* * *}$ \\
\hline Criança lê ocasionalmente & $0,713598^{* * *}$ & 0,019063 & $-0,252472^{* * *}$ & $-0,242396^{* * *}$ & $0,362367^{* * *}$ & $0,450339 * * *$ \\
\hline Criança lê frequentemente & $1,013520 * * *$ & 0,052566 & $-0,335366^{* * *}$ & $-0,349221^{* * *}$ & $0,553132^{* * *}$ & $0,846670^{* * *}$ \\
\hline Escola na Área urbana & 0,004707 & $0,100835^{* *}$ & $0,175808^{*}$ & $0,126302^{* *}$ & $-0,083466^{*}$ & 0,054672 \\
\hline
\end{tabular}

Nota: * Significante a $10 \%$; ** Significante a $5 \%$; ** Significante a $1 \%$. Cada linha dessa tabela representa o coeficiente da variável explicativa da regressão entre uma das variáveis de habilidade socioemocional e o indicador de crimes contra patrimônio. Fonte: Elaboração própria com dados do ISP-RJ (2012-2013) e base SENNA 2013. 
Tabela 22 - Relação entre Habilidades Socioemocionais e Violência por Quantil - $1^{\circ}$ ano do EM

\begin{tabular}{lllllll}
\hline \hline & Consciec. & Extroversão & Est. Emoc. & Loc. Contr. & Amabilidade & Abertura \\
\hline \multicolumn{7}{c}{ Crimes Violentos Letais e Intencionais } \\
\hline q10 & $0,001563^{* *}$ & 0,000214 & $0,002031^{* *}$ & $-0,000895$ & $-0,000220$ & $-0,000259$ \\
q25 & $0,002268^{* * *}$ & $-0,000013$ & 0,000958 & 0,000257 & 0,000337 & $-0,000078$ \\
q50 & $0,002124^{* * *}$ & $-0,001115^{*}$ & $-0,000062$ & $-0,000379$ & 0,000585 & 0,000934 \\
q75 & $0,002420^{* * *}$ & $-0,000967$ & 0,000984 & $-0,000603$ & 0,000012 & 0,000382 \\
q90 & $0,002140^{* *}$ & $-0,000149$ & $-0,000077$ & $-0,000883$ & 0,000280 & $-0,000193$ \\
\hline \multicolumn{7}{c}{ Crimes Violentos Não Letais Contra a Pessoa } \\
\hline q10 & $0,000163^{* *}$ & $-0,000148^{*}$ & $-0,000078$ & $-0,000027$ & $-0,000439^{* * *}$ & $-0,000189^{* *}$ \\
q25 & 0,000073 & $-0,000188^{* * *}$ & $-0,000001$ & $-0,000019$ & $-0,000270^{* * *}$ & $-0,000147^{* *}$ \\
q50 & 0,000035 & $-0,000128^{*}$ & $-0,000085$ & $-0,000016$ & $-0,000202^{* * *}$ & $-0,000130^{*}$ \\
q75 & 0,000004 & $-0,000124$ & $-0,000051$ & $-0,000058$ & $-0,000182^{*}$ & $-0,000022$ \\
q90 & $-0,000206^{*}$ & $-0,000144$ & $-0,000147$ & 0,000069 & $-0,000323^{* * *}$ & $-0,000050$ \\
\hline \multicolumn{7}{c}{ Crimes Contra Patrimônio } \\
\hline q10 & $0,000041^{*}$ & $-0,000051^{* *}$ & $-0,000059^{* *}$ & 0,000005 & $-0,000115^{* * *}$ & $-0,000054^{* *}$ \\
q25 & 0,000027 & $-0,000065^{* * *}$ & $-0,000040^{*}$ & 0,000001 & $-0,000127^{* * *}$ & $-0,000043^{* *}$ \\
q50 & 0,000013 & $-0,000034^{*}$ & $-0,000034^{*}$ & $-0,000010$ & $-0,000123^{* * *}$ & $-0,000045^{* *}$ \\
q75 & 0,000022 & $-0,000051^{* *}$ & $-0,000034$ & $-0,000017$ & $-0,000084^{* * *}$ & $-0,000058^{* * *}$ \\
q90 & $-0,000043$ & $-0,000058^{*}$ & 0,000001 & 0,000018 & $-0,000089^{* *}$ & $-0,000086^{* * *}$ \\
\hline \hline
\end{tabular}

Nota: * Significante a $10 \%$; $*$ Significante a $5 \%$;** Significante a $1 \%$. Cada entrada dessa tabela representa o coeficiente de uma regressão quantílica. Em todos os casos, as variáveis de controle utilizadas foram: sexo; idade; raça; nível de educação da mãe; se jovem mora com a mãe; se pais são alfabetizados; número de livros no domicílio; se família recebe Bolsa Família; se há calçadas, energia, água, saneamento e serviço doméstico onde vivem; quantos banheiros, refrigeradores, máquinas de lavar, DVDs, automóveis, dicionários há no domicílio; se há computador com internet no domicílio; hábitos de leitura dos pais e dos filhos; se pais incentivam a leitura; notas de português e matemática do SAERJINHO. Os erros-padrão corrigidos por clusters de delegacias são apresentados entre parênteses. Fonte: Elaboração própria com dados do ISP-RJ (2012-2013) e base SENNA 2013. 
Tabela 23 - Relação entre Habilidades Socioemocionais e Violência por Quantil - $3^{\circ}$ ano do EM

\begin{tabular}{|c|c|c|c|c|c|c|}
\hline & Consciec. & Extroversão & Est. Emoc. & Loc. Contr. & Amabilidade & Abertura \\
\hline \multicolumn{7}{|c|}{ Crimes Violentos Letais e Intencionais } \\
\hline q10 & 0,000965 & $-0,000891$ & 0,000397 & $-0,001722$ & 0,001161 & $-0,000886$ \\
\hline q25 & $-0,000196$ & $-0,001063$ & 0,001070 & $-0,001292$ & 0,000101 & $-0,000533$ \\
\hline q50 & 0,000308 & $-0,001023$ & 0,001148 & $-0,000912$ & 0,000816 & $-0,000281$ \\
\hline q75 & 0,000470 & $-0,000038$ & $0,001891^{* *}$ & $-0,001155$ & 0,001061 & 0,000692 \\
\hline q90 & $-0,000554$ & 0,000674 & 0,000793 & $-0,000600$ & 0,001699 & 0,000436 \\
\hline \multicolumn{7}{|c|}{ Crimes Violentos Não Letais Contra a Pessoa } \\
\hline q10 & 0,000073 & $-0,000030$ & 0,000091 & $-0,000142$ & $0,000177^{*}$ & 0,000053 \\
\hline q25 & $-0,000046$ & $-0,000014$ & 0,000087 & $-0,000058$ & 0,000166 & 0,000119 \\
\hline q50 & $-0,000079$ & $-0,000050$ & 0,000076 & $-0,000028$ & 0,000087 & 0,000011 \\
\hline q75 & $-0,000027$ & 0,000096 & 0,000107 & 0,000042 & 0,000158 & $0,000248^{* *}$ \\
\hline q90 & $-0,000140$ & $0,000413^{* *}$ & 0,000237 & $-0,000051$ & $-0,000010$ & $0,000321^{* *}$ \\
\hline \multicolumn{7}{|c|}{ Crimes Contra Patrimônio } \\
\hline q10 & $-0,000017$ & $-0,000062^{*}$ & $-0,000078^{*}$ & $-0,000056^{* * *}$ & $-0,000077^{* *}$ & $-0,000061^{* *}$ \\
\hline q25 & $-0,000018$ & $-0,000032$ & $-0,000050$ & $-0,000059^{* *}$ & $-0,000096^{* * *}$ & $-0,000057^{* *}$ \\
\hline q50 & $-0,000011$ & $-0,000043^{*}$ & $-0,000056^{* *}$ & $-0,000009$ & $-0,000058^{* *}$ & $-0,000050^{* *}$ \\
\hline q75 & 0,000009 & $-0,000053$ & $-0,000009$ & $-0,000023$ & $-0,000074^{* *}$ & $-0,000024$ \\
\hline q90 & $-0,000001$ & $-0,000046$ & $0,000079^{*}$ & $-0,000060$ & $-0,000067$ & 0,000030 \\
\hline \multicolumn{7}{|c|}{$\begin{array}{l}\text { Nota: * Significante a } 10 \% \text {; } * * \text { Significante a } 5 \% ; * * \text { Significante a } 1 \% \text {. Cada entrada dessa tabela } \\
\text { representa o coeficiente de uma regressão quantílica. Em todos os casos, as variáveis de controle utilizadas } \\
\text { foram: sexo; idade; raça; nível de educação da mãe; se jovem mora com a mãe; se pais são alfabetizados; } \\
\text { número de livros no domicílio; se família recebe Bolsa Família; se há calçadas, energia, água, saneamento } \\
\text { e serviço doméstico onde vivem; quantos banheiros, refrigeradores, máquinas de lavar, DVDs, automóveis, } \\
\text { dicionários há no domicílio; se há computador com internet no domicílio; hábitos de leitura dos pais e dos } \\
\text { filhos; se pais incentivam a leitura; notas de português e matemática do SAERJINHO. Os erros-padrão } \\
\text { corrigidos por clusters de delegacias são apresentados entre parênteses. Fonte: Elaboração própria com } \\
\text { dados do ISP-RJ (2012-2013) e base SENNA } 2013 \text {. }\end{array}$} \\
\hline
\end{tabular}

